\title{
Blue Mountain and The Gas Rocks: Rear-Arc Dome Clusters on the Alaska Peninsula
}

\author{
By Wes Hildreth, Judy Fierstein, and Andrew T. Calvert
}

\section{Abstract}

Behind the single-file chain of stratovolcanoes on the Alaska Peninsula, independent rear-arc vents for mafic magmas are uncommon, and for silicic magmas rarer still. We report here the characteristics, compositions, and ages of two andesite-dacite dome clusters and of several nearby basaltic units, all near Becharof Lake and 15 to $20 \mathrm{~km}$ behind the volcanic front. Blue Mountain consists of 13 domes (58-68 weight percent $\mathrm{SiO}_{2}$ ) and The Gas Rocks of three domes (62-64.5 weight percent $\mathrm{SiO}_{2}$ ) and a mafic cone (52 weight percent $\mathrm{SiO}_{2}$ ). All 16 domes are amphibole-biotite-plagioclase felsite, and nearly all are phenocryst rich and quartz bearing. Although the two dome clusters are lithologically and chemically similar and only $25 \mathrm{~km}$ apart, they differ strikingly in age. The main central dome of Blue Mountain yields an ${ }^{40} \mathrm{Ar} /{ }^{39} \mathrm{Ar}$ age of $632 \pm 7 \mathrm{ka}$, and two of the Gas Rocks domes ages of $25.7 \pm 1.4$ and $23.3 \pm 1.2 \mathrm{ka}$. Both clusters were severely eroded by glaciation; surviving volumes of Blue Mountain domes total $\sim 1 \mathrm{~km}^{3}$, and of the Gas Rocks domes $0.035 \mathrm{~km}^{3}$. Three basaltic vents lie close to The Gas Rocks, another lies just south of Blue Mountain, and a fifth is near the north shore of Becharof Lake. A basaltic andesite vent $6 \mathrm{~km}$ southeast of The Gas Rocks appears to be a flank vent of the arc-front center Mount Peulik. The basalt of Ukinrek Maars has been called transitionally alkalic, but all the other basaltic rocks are subalkaline. $\mathrm{CO}_{2}$-rich gas emissions near the eponymous Gas Rocks domes are not related to the 25-ka dacite dome cluster but, rather, to intracrustal degassing of intrusive basalt, one batch of which erupted 3 $\mathrm{km}$ away in 1977. The felsic and mafic vents all lie along or near the Bruin Bay Fault where it intersects a broad transverse structural zone marked by topographic, volcanologic, and geophysical discontinuities.

\section{Introduction}

Blue Mountain and The Gas Rocks are discrete clusters of Pleistocene dacite lava domes, $25 \mathrm{~km}$ apart, within the Bristol Bay Lowland of the Alaska Peninsula (fig. 1). The dome clusters lie 90 to $110 \mathrm{~km}$ south of King Salmon (the princi- pal nearby town) and 15 to $20 \mathrm{~km}$ behind (northwest of) the volcanic-front chain, which is locally defined by Kejulik and Peulik stratovolcanoes (fig. 1). The Gas Rocks form a knobby peninsula at the south shore of Becharof Lake, and Blue Mountain is a group of rounded hills a few kilometers west of Upper Ugashik Lake (fig. 2). Both dome clusters rise abruptly above a nearly flat (virtually treeless and roadless) plain of late Pleistocene glacial deposits (Detterman and others, 1987a, b), consisting largely of till and outwash, supplemented by the bog and lacustrine deposits of hundreds of ponds and by beach and terrace deposits along the lakeshores. The enormous moraine-dammed lakes (fig. 2) are generally shallower than $5 \mathrm{~m}$, and their surfaces are barely $10 \mathrm{~m}$ above sea level. Their basins were formerly occupied by piedmont lobes of the ice that blanketed the adjacent Aleutian Range, the highland backbone of the Alaska Peninsula. This rugged axial highland consists largely of Mesozoic sedimentary rocks, overlain only locally along this particular reach by widely spaced Quaternary stratovolcanoes (Detterman and others, 1981, 1987a; Riehle and others, 1993). During episodes of maximal glacial expansion, ice sheets blanketed most of the Bristol Bay Lowland, completely covering The Gas Rocks once and the older Blue Mountain cluster several times.

The Quaternary volcanic arc studding the Alaska Peninsula and the Aleutian Islands is a segmented, but largely single file, chain of volcanic centers that contrasts markedly with the Japanese, Cascadian, Mexican, and Andean arcs, where the Quaternary volcanic belts are many tens of kilometers wide-with dozens to hundreds of arc volcanoes scattered across the rear arc, extending far behind the volcanic front. Along the Alaskan chain, however, only a few rear-arc centers have been described-Amak and Bogoslof Islands (Wood and Kienle, 1990), Mount Griggs (Hildreth and others, 2002), and 13 monogenetic volcanoes in the Katmai district (Hildreth and others, 2004). Although dacite is common at many volcanic-front centers along the Alaska Peninsula (Hildreth and Fierstein, 2000, 2003; Hildreth and others, 2004; Miller, 2004), nearly all the eruptive products in the rear arc here are basaltic or andesitic. The Gas Rocks and Blue Mountain, the principal subjects of this report, are therefore manifoldly anomalous - as rear-arc volcanoes, as clusters of rear-arc dacite domes, and in there being two such clusters only $25 \mathrm{~km}$ apart. 


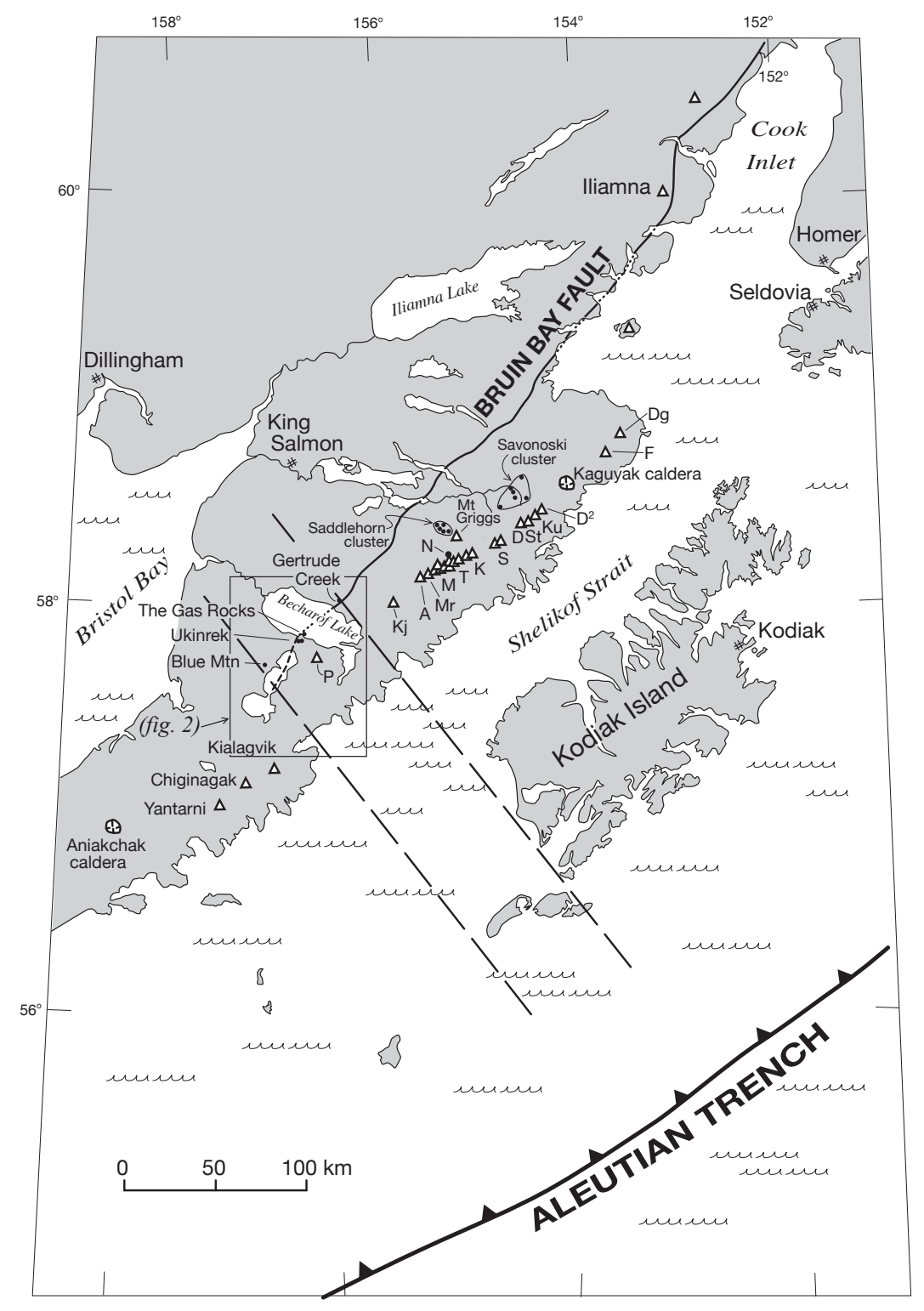

Figure 1. Upper part of the Alaska Peninsula, showing location of study area near southwest end of the Bruin Bay Fault and rear-arc situation of Blue Mountain, The Gas Rocks, Ukinrek Maars, and Gertrude Creek volcanoes. Main chain of arc-front stratovolcanoes (triangles) includes, from southwest to northeast: P, Peulik; Kj, Kejulik; A, Alagogshak; Mr, Martin; M, Mageik (cluster of four); $T$, Trident (cluster of four); K, Katmai (two cones); $S$, Snowy Mountain (two cones); D, Denison; St, Steller; Ku, Kukak; D2, Devils Desk; F, Fourpeaked; and $\mathrm{Dg}$, Douglas. Novarupta (N) was vent for great 1912 eruption in the Valley of Ten Thousand Smokes (Hildreth and Fierstein, 2000, 2003). Volcanic-front segment southwest of Blue Mountain is offset seaward from Peulik-to-Douglas segment. Additional rear-arc volcanoes shown are the Savonoski River cluster (Pleistocene), the Saddlehorn Creek cluster (Pliocene), and active Mount Griggs (Hildreth and others, 2002, 2004), all of which lie 11 to $22 \mathrm{~km}$ behind tightly spaced frontal chain of the Katmai reach. The Aleutian Trench lies 350 $\mathrm{km}$ seaward of volcanic front, separated from it by a still-growing accretionary wedge of imbricate, sediment-dominated terranes of Mesozoic and Cenozoic age. Pair of dashed lines delimit cryptic transverse structural zone proposed by Fisher and others (1981). 


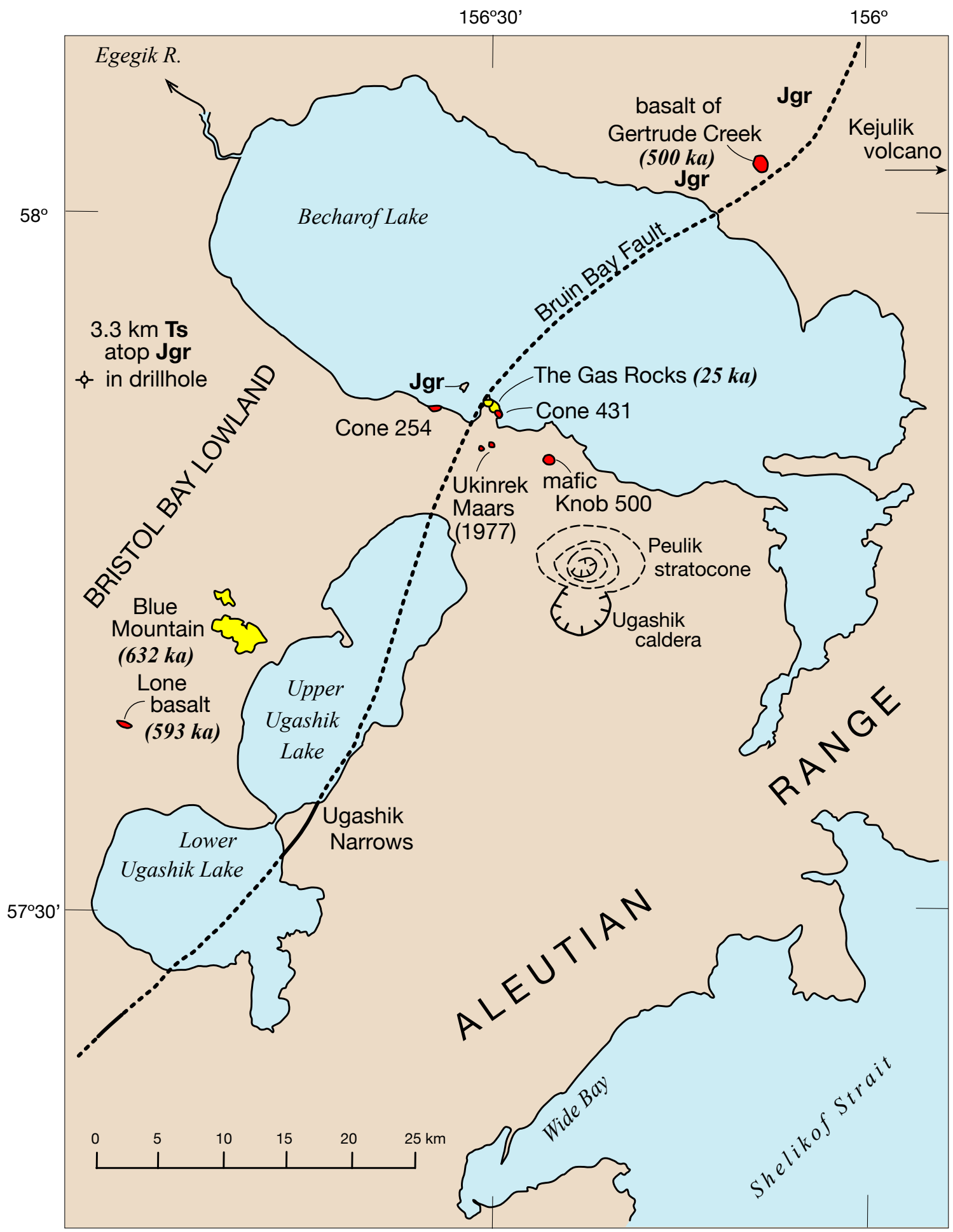

Figure 2. Study area on upper part of the Alaska Peninsula (fig. 1), showing two dacite dome clusters (yellow areas) and six nearby basaltic units (red areas) relative to the Bruin Bay Fault and to arc-front Peulik stratovolcano. Trace of largely concealed fault after Detterman and others (1987a). Holocene cone of Mount Peulik is shown schematically, neglecting its complex fragmental apron (Miller, 2004). Pre-Quaternary basement southeast of fault is largely composed of Jurassic sedimentary rocks. Northwest of fault, exposed basement consists predominantly of Jurassic granitoids (unit Jgr) north of Becharof Lake (and on islet near The Gas Rocks), but south of Becharof Lake granitoids are covered by $>3 \mathrm{~km}$ of Tertiary clastic sedimentary rocks (unit Ts; MacNeil and others, 1961), which, in turn, are wholly concealed by glacial and other surficial deposits. 
Studies by the U.S. Geological Survey in Alaska, 2006

\section{Geologic Setting}

We avoid use of the term "backarc" volcanoes here because the tectonic and magmatic processes involved in backarc spreading behind intraoceanic island arcs are not evident on the Alaska Peninsula. Other geologists have referred to rear-arc centers as "behind the front," but we prefer our terminology because it acknowledges the clear (though commonly subdued) arc geochemical signature (Hildreth and others, 2004) and because many intraplate (non-arc) basalts elsewhere also erupt "behind" arc fronts.

The Mesozoic rocks upon which the arc and rear-arc volcanic products were erupted belong to the Peninsular tectonostratigraphic terrane, which is thought to have originated far to the south and to have been added to southern Alaska in the late Mesozoic (Plafker and Berg, 1994; Plafker and others, 1994). The crustal structure here is poorly known, and the composition of the basement beneath the Mesozoic marine section southeast of the Bruin Bay Fault (fig. 1) remains especially uncertain. The Alaska Peninsula crust is thought to be 30 to 36 $\mathrm{km}$ thick farther to the northeast (Moore and others, 1991), as well as near the southwest extremity of the peninsula (Fliedner and Klemperer, 2000). Although the lower crust beneath the forearc and volcanic arc may be unusually mafic, with atypically high seismic velocities for continental crust (Fliedner and Klemperer, 2000), the many Tertiary granitoid plutons along the peninsula (Detterman and others, 1981, 1987a; Riehle and others, 1993) indicate that much of the subarc crust is now effectively continental.

The Bruin Bay Fault (figs. 1, 2), near which both Blue Mountain and The Gas Rocks erupted, is a profound highangle geologic boundary that extends $>500 \mathrm{~km}$ northeastward from the Ugashik Lakes (fig. 2). In this area, the fault juxtaposes Middle Jurassic granitoids (Reed and Lanphere, 1972, 1973) and their metamorphosed wallrocks on the northwest against Upper Jurassic and younger marine sedimentary strata (Detterman and others, 1996) on the southeast. Major strikeslip offset (Detterman and Reed, 1980) probably took place during the Cretaceous, though important high-angle reverse dip-slip displacement appears to have been superimposed subsequently, possibly during the anticlockwise rotation of southwestern Alaska, which continued into the Eocene (Plafker and others, 1994). The fault zone is intruded near Kulik Lake (150 km northeast of The Gas Rocks) by several undisturbed granitoid plutons, dated at 25-28 Ma by Reed and Lanphere (1972, 1973), apparently negating any post-Oligocene movement. No Quaternary or Neogene displacement on the fault has been documented.

The Aleutian Trench (5-6 km below sea level) lies $350 \mathrm{~km}$ southeast of the arc front (fig. 1). Eocene sea floor is now being subducted nearly orthogonally there, at a convergence rate of 6 $\mathrm{cm} / \mathrm{yr}$. The inclined seismic zone is well defined and 20 to 30 $\mathrm{km}$ thick (Kienle and others, 1983); it dips only about $10^{\circ} \mathrm{NNW}$. for some $300 \mathrm{~km}$ landward of the trench, where it steepens to $\sim 45^{\circ}$ beneath the present-day arc front, and persists behind the front to depths as great as $200 \mathrm{~km}$. The top of the seismic zone lies $\sim 100 \mathrm{~km}$ beneath the arc front near Mount Katmai but may deepen slightly along the front to the southwest (Kienle and others, 1983). Because the rear-arc volcanoes considered here lie 15 to $20 \mathrm{~km}$ behind the front, the top of the $45^{\circ}$-dipping seismic zone beneath them may be as deep as $130 \mathrm{~km}$.

The nearest andesite-dacite stratovolcanoes of the main chain (figs. 1, 2) are Mount Peulik, a Holocene cone only $15 \mathrm{~km}$ southeast of The Gas Rocks, and Kejulik Volcano, an erosionally dissected early Pleistocene cone centered $55 \mathrm{~km}$ east-northeast of The Gas Rocks. The Kialagvik-ChiginagakYantarni stratocone alignment, 70 to $110 \mathrm{~km}$ south-southeast of The Gas Rocks, constitutes a discrete arc segment that is clearly offset seaward from the trend of the Peulik-KejulikKatmai chain (fig. 1). All of these arc-front centers except Kejulik have erupted in the Holocene (Wood and Kienle, 1990), and Peulik and Chiginagak are thought to have undergone minor historical activity (Miller and others, 1998). Peulik was shown by interferometric-synthetic-aperture-radar (InSAR) satellite imagery to have undergone $\sim 17 \mathrm{~cm}$ of uplift centered on Ugashik caldera (fig. 2) between October 1996 and September 1997 (Lu and others, 2002). The only welldocumented historical eruption in the immediate area was the basaltic phreatomagmatic formation of Ukinrek Maars in 1977 (Kienle and others (1980), just $3 \mathrm{~km}$ south of The Gas Rocks. A swarm of earthquakes, centered $20 \mathrm{~km}$ west-northwest of The Gas Rocks (and the Bruin Bay Fault), took place beneath the western part of Becharof Lake in 1998; most of the hypocenters were calculated to have been shallower than $7 \mathrm{~km}(\mathrm{Lu}$ and others, 2002). More than 400 seismic events were detected there in the 5 months after the 8 May onset, but more than 80 percent of the seismic moment was registered in the first few hours, when earthquakes of $\mathrm{M}=5.2,4.8$, and 5.1 took place.

\section{Previous Work}

Little attention has previously been paid to Blue Mountain and The Gas Rocks. They were lumped with all other Quaternary volcanic rocks on the 1:250,000-scale geologic maps of Detterman and others (1987a, b), who mentioned discordant $\mathrm{K}$-Ar age determinations of 1.66 and $0.55 \mathrm{Ma}$ for Blue Mountain and 0.61 and 0.13 Ma for The Gas Rocks. These and additional highly discordant K-Ar mineral ages for both clusters were tabulated by Wilson and Shew (1992). Miller (2004) prepared a 1:63,360-scale reconnaissance geologic map of nearby Mount Peulik that extends northward to The Gas Rocks, which he generalized as a single dacite dome. The eruptive sequence, dynamics, and products of the 1977 basaltic eruption at nearby Ukinrek Maars were investigated by Kienle and others (1980) and Self and others (1980). Descriptive and compositional data for a small 500-ka basaltic cone at Gertrude Creek, just north of Becharof Lake (fig. 2), were reported by Hildreth and others (2003, 2004). Chemical and isotopic data for $\mathrm{CO}_{2}$-rich gases issuing through and adjacent to The Gas Rocks and Ukinrek 
Maars, as well as data for associated water samples, were reported by Barnes and McCoy (1979), Motyka and others (1993), and Symonds and others (1997).

The U.S. Geological Survey (USGS) topographic maps used for our fieldwork are the 1:63,360-scale Ugashik C-3 and D-2 quadrangles. Because no maps in the district use S.I. units, we cite elevations in feet $(1 \mathrm{~m}=3.281 \mathrm{ft})$. Certain unnamed eminences are here referred to by their elevations in feet (for example, Cone 431) or, where no specific elevation is given, by the elevation of the highest mapped contour (for example, Dome 700).

\section{Blue Mountain}

Blue Mountain consists of 13 dacite domes in a cluster $\sim 6 \mathrm{~km}$ long (figs. 3, 4), similar in extent and configuration to what the Kaguyak dome cluster, $200 \mathrm{~km}$ to the northeast (fig. 1), had been before its mid-Holocene caldera-forming eruption (Fierstein and Hildreth, in press). Three of the Blue Mountain domes form a separate group (figs. 3, 5), 1 km north of the main cluster, although they are chemically and mineralogically similar to the rest. The two large central domes (Domes 1776, 1700, fig. $3 A$ ) abut each other and together form the main ridge of the Blue Mountain edifice. From each dome issued stubby 200-m-thick flow lobes that form three southerly trending ridges (figs. 3, 6). Eight satellite domes are contiguous with the central ridge, four at its northwest end and four at its southeast end (figs. 3, 4, 6, 7). The smallest domes have as little as $100 \mathrm{~m}$ of relief, and the four largest stand $>300 \mathrm{~m}$ above the surrounding apron of glacial and colluvial deposits.

All but one of the lava domes sampled consist of phenocryst-rich felsite, from which most of the primary glassy external facies has been scoured away by recurrent glaciations. Although the domes are widely mantled by colluvium, many good exposures are available. The rocks are generally massive, though brecciated, block jointed, or cut by steep vertical joint sets in a few places; most of the rocks are nonvesicular or contain only sparse irregular vugs, 1 to $2 \mathrm{~mm}$ across. Because of lithologic and mineralogic similarities, we refer to all the domes as dacite, although their compositional array is continuous from 61 to 68 weight percent $\mathrm{SiO}_{2}$ (fig. 8). Sample U-22 from Dome 1151 (fig. 3A) is exceptional in being strongly andesitic (58 weight percent $\mathrm{SiO}_{2}$ ), yet it is richer in $\mathrm{K}, \mathrm{Sr}, \mathrm{Zr}$, and $\mathrm{Ba}$ than would be an extension of the more silicic Blue Mountain compositional array (fig. 8; table 1).

Most of the lavas contain 25 to 35 volume percent phenocrysts, dominantly plagioclase but also several volume percent each of biotite and amphibole and 1 to 2 volume percent Fe-Ti oxide microphenocrysts. Of 15 such crystal-rich samples from Blue Mountain that we examined, the 11 containing more than 62.5 weight percent $\mathrm{SiO}_{2}$ additionally contain 1 to 3 volume percent quartz phenocrysts (1-2.5 $\mathrm{mm}$ diam), whereas quartz is rare or absent in the four with lower $\mathrm{SiO}_{2}$ contents. Most of the quartz is subhedral but rounded, many grains contain glass (melt) inclusions, and some grains are embayed or broken. Plagioclase is twinned and zoned, euhedral or subhedral, and either solitary or in multicrystalline intergrowths, as big as $7 \mathrm{~mm}$ across. Only a few feldspar grains are sieve textured, either pervasively or in concentric zones inboard of clear rims. Both biotite and amphibole (1-5 mm diam) are ubiquitous, conspicuous, and commonly oxidized. Either mineral may exceed the other in abundance, although no correlation was observed between their relative proportions and bulk composition. Groundmass textures of all the domes sampled are finely microcrystalline (with or without sparse residual glass) but sprinkled with microlites and with microphenocrysts of all phenocrystic phases except quartz.

Finely granular enclaves (1-25 cm diam) were noted in many of the domes, and blocks of similar material, as big as $1 \mathrm{~m}$ across, are present in Dome 971 (fig. 3A). The four such enclaves sampled contain 51 to 56 weight percent $\mathrm{SiO}_{2}$ (fig. 8). Each sample consists of holocrystalline intergrowths of elongate $(0.5-1 \mathrm{~mm}$ diam) plagioclase and amphibole with subordinate biotite and Fe-Ti oxides, plus sparse larger (1-3 $\mathrm{mm}$ diam) plagioclase crystals likely to have been incorporated from the host dacite.

At the north end of the main cluster, small Dome 1200 is exceptional in containing only 5 volume percent phenocrysts, in comparison with 25 to 35 volume percent in all other units. Our sample (U-12) has the same phenocryst suite as the other domes (although quartz and oxides are sparse) as well as a comparably fine crystalline groundmass. The sample contains 66.1 weight percent $\mathrm{SiO}_{2}$ (near the upper end of the Blue Mountain compositional array, fig. 8), and its principal distinction is a relative deficiency in $\mathrm{K}$ and $\mathrm{Rb}$ (fig. 8; table 1). At the south end, andesitic Dome 1151 (sample U-22) also is poorer in phenocrysts $(\sim 15$ volume percent $)$ than most other samples, although the mineral suite is again the same.

A single ${ }^{40} \mathrm{Ar} /{ }^{39} \mathrm{Ar}$ age was determined for Blue Mountain, on a groundmass concentrate of dacite sample U-19 (table 1) from the south-trending ridge of summit Dome 1776 (figs. $3 A, 6$ ). Its weighted-mean plateau age is $632 \pm 7$ ka (fig. 9; table 2), categorically middle Pleistocene and about 25 times older than the lithologically and compositionally similar domes at The Gas Rocks. At Blue Mountain, the several satellitic domes surrounding dated Dome 1776 (fig. 3) are unlikely to differ much in age, although the noncontiguous northern group might conceivably do so. We discerned no significant differences in degree of erosion, and the chemical and petrographic similarities of nearly all the domes in both groups suggest no basis for inferring an exceptionally protracted eruptive sequence.

The global marine oxygen-isotope record (for example, Shackleton, 1995) suggests at least five major glacial expansions since $632 \mathrm{ka}$, implying that Blue Mountain was overridden by ice as many times. All the domes have been stripped of their primary pumiceous or glassy carapace, and the steep northeastern and southwestern margins of the main edifice (F.H., 1981, Geologic map of the Chignik and Sutwik Island (figs. 6,7) suggest truncation by the ice sheets that recurrently spread northwestward from the site of Upper Ugashik Lake 

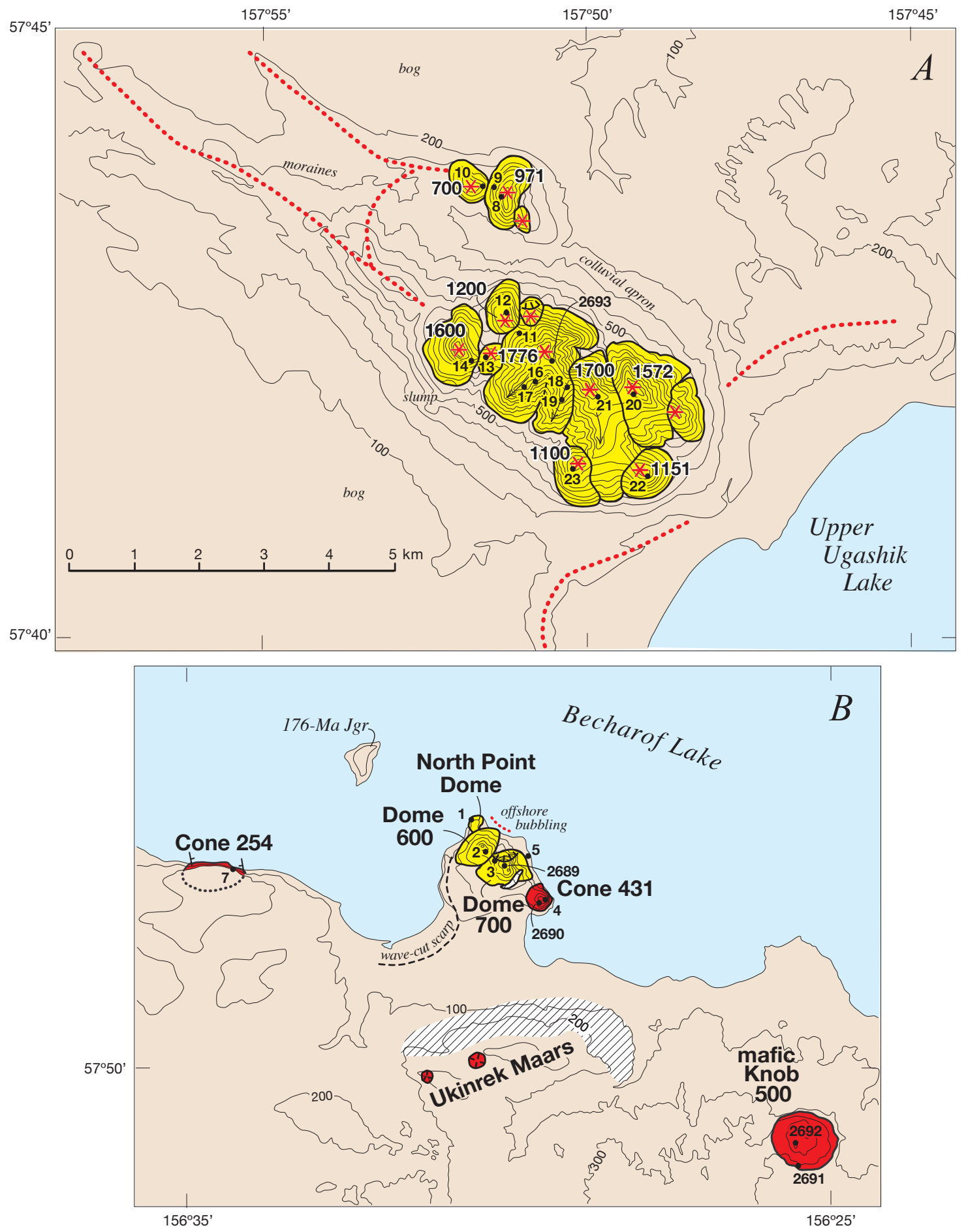

Figure 3. Site maps of Blue Mountain and The Gas Rocks, at same scale (see fig. 1 for locations). A, Blue Mountain dome cluster (yellow areas), surrounded by its own colluvial apron and by glacial and bog deposits. Arrows denote lava-flow lobes. Red dotted lines, moraine crests; red asterisks, sites of effusion. $B$, The Gas Rocks dome cluster (yellow areas) and four nearby sites of mafic eruption (red areas). Principal area of gas bubbling through lake (red dotted line) is just offshore of domes. Area of active bubbling seeps and vegetation kill identified by Evans and others (2007) is indicated by crosslined pattern along low ridge north and east of Ukinrek Maars, which formed explosively in 1977. Lowland surroundings are mostly lake-terrace or glacial deposits and a hummocky postglacial debris-avalanche deposit from the Peulik-Ugashik volcanic center (Miller, 2004). Numbered dots, locations of samples listed in tables 1 and 2. Hachured area, landslide scarps shown in figures 7 and 12 . 


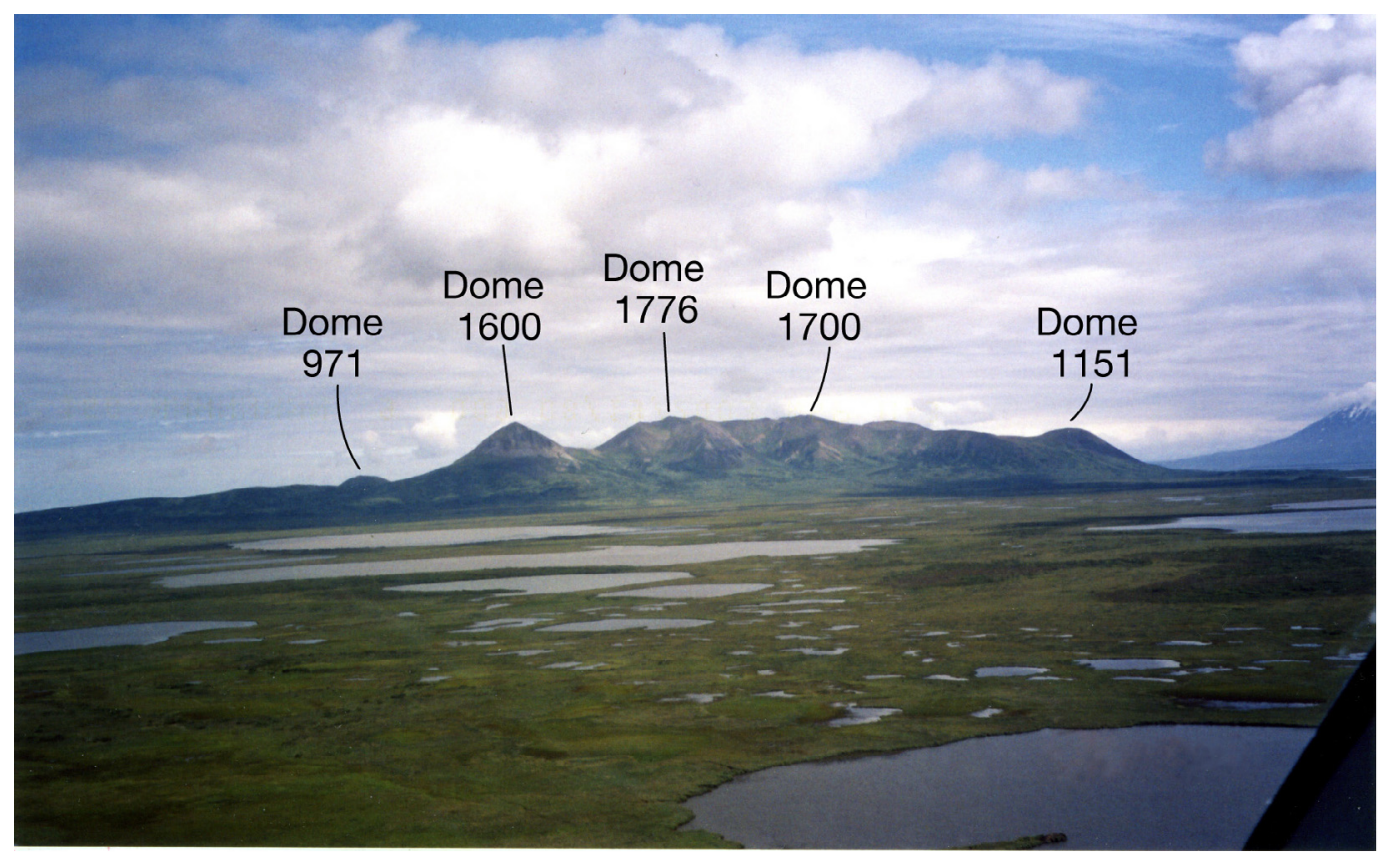

Figure 4. Blue Mountain dome cluster (figs. 2, 3A), $6 \mathrm{~km}$ long, viewed northeastward across $8 \mathrm{~km}$ of muskeg. From left to right, a linear moraine conceals all but the top of Dome 971 (on horizon to left); Dome 1600 appears symmetrically conical; summit ridge at center extends from Dome 1776 to Dome 1700; and rounded Dome 1151 stands out as southern buttress of cluster. Ponds in foreground and middle distance are $\sim 50 \mathrm{ft}(15 \mathrm{~m})$ above sea level. This photograph and others below were taken in late July or early August 2003.

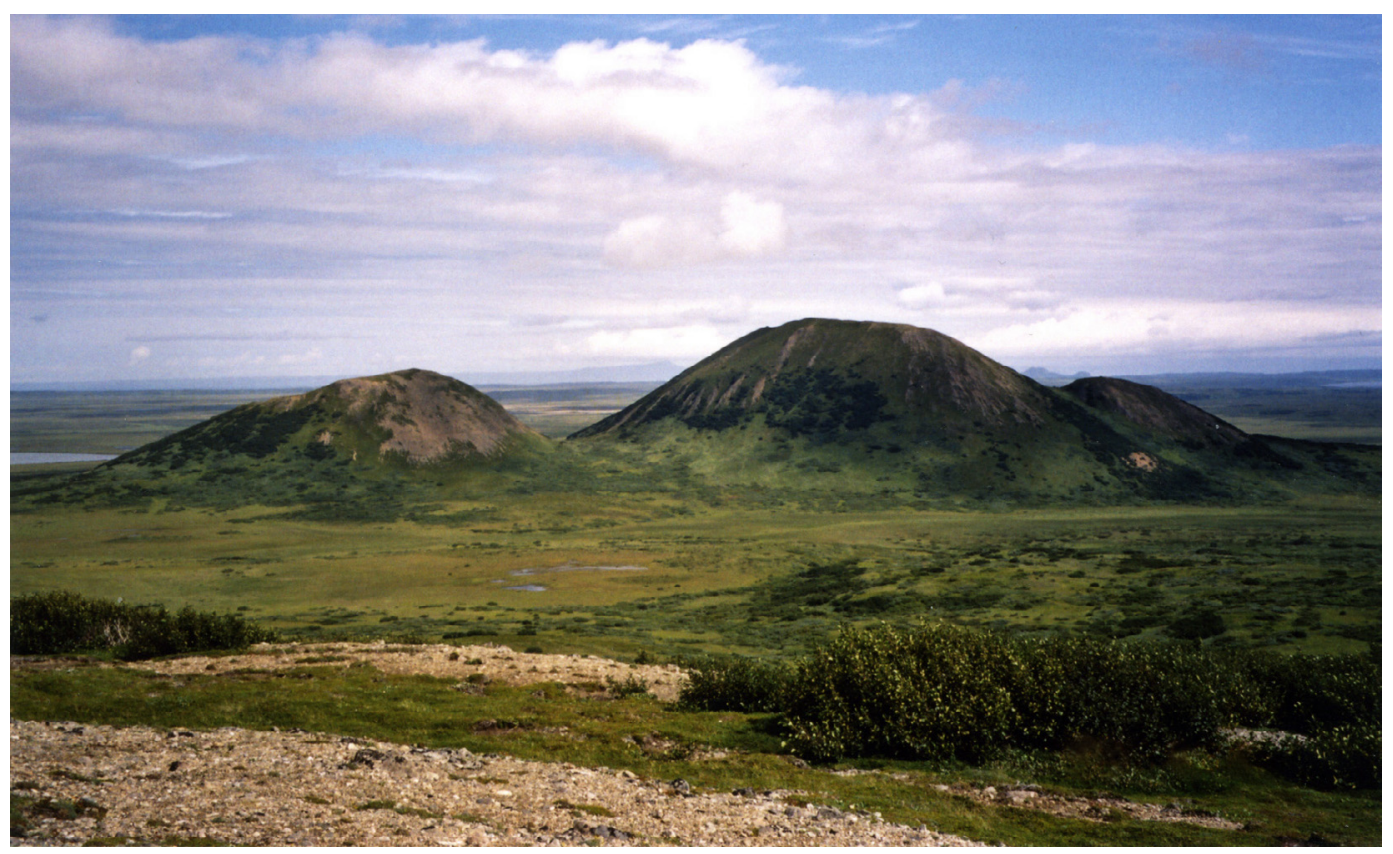

Figure 5. Detached northern cluster of three Blue Mountain dacite domes (figs. 2, 3A), viewed northeastward from linear ridge of glacial deposits that extends northwest from the main cluster. From left to right, Dome 700, Dome 971, and small southeastern dome. On horizon above saddle between the latter pair are The Gas Rocks, $25 \mathrm{~km}$ northeast. Marshy foreground is $\sim 300 \mathrm{ft}(90 \mathrm{~m})$ above sea level. 


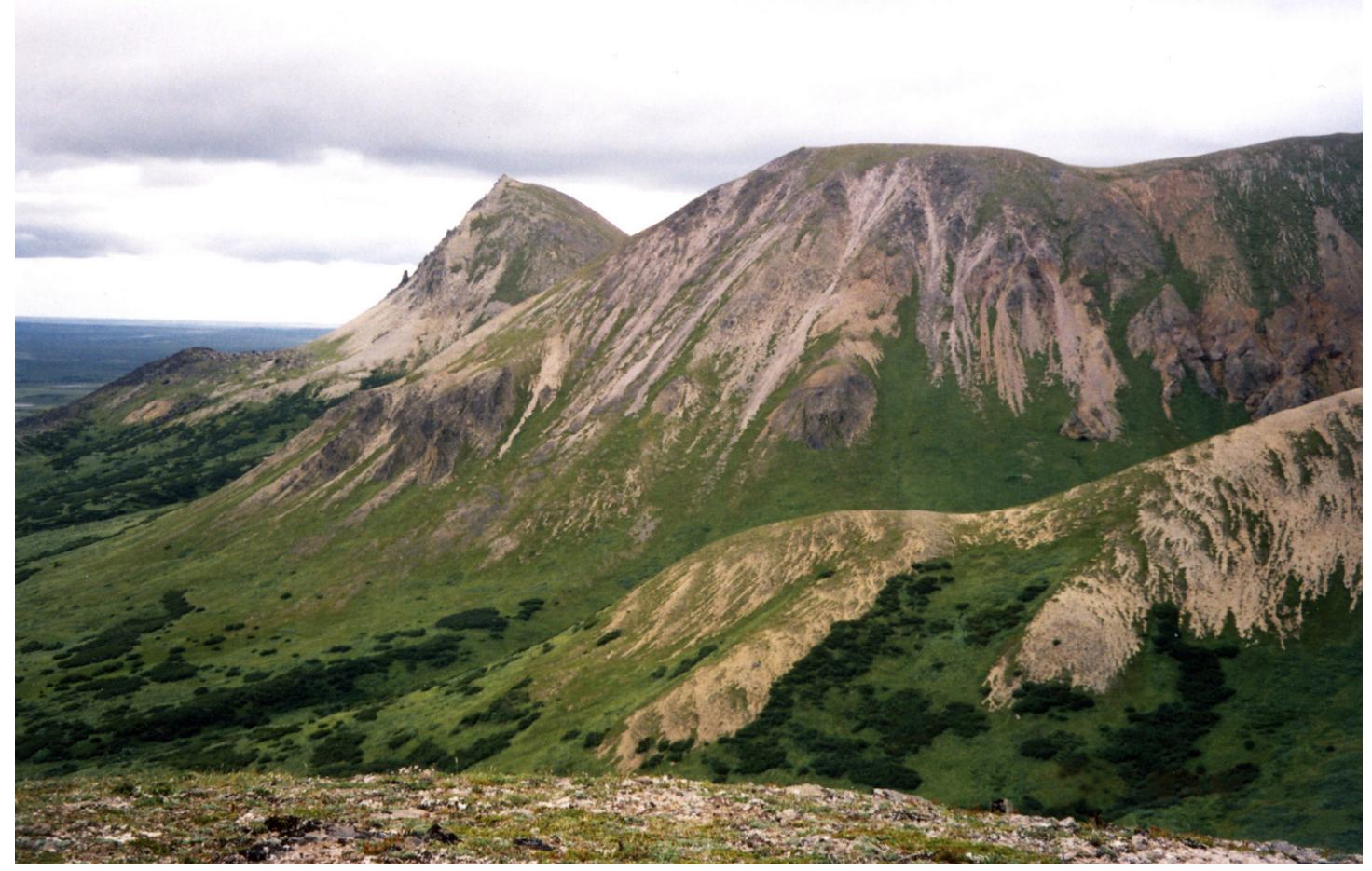

Figure 6. Southwest-facing scarp of Blue Mountain dome cluster (figs. 2, 3A), steepened by glacial erosion; viewed toward northwest from atop Dome 1100. High half-dome in left background is Dome 1600. At center is flat-topped southwest ridge of summit dome (Dome 1776, out of view to right). Low ridge in foreground is a stubby coulee that extends south-southwestward from summit dome.

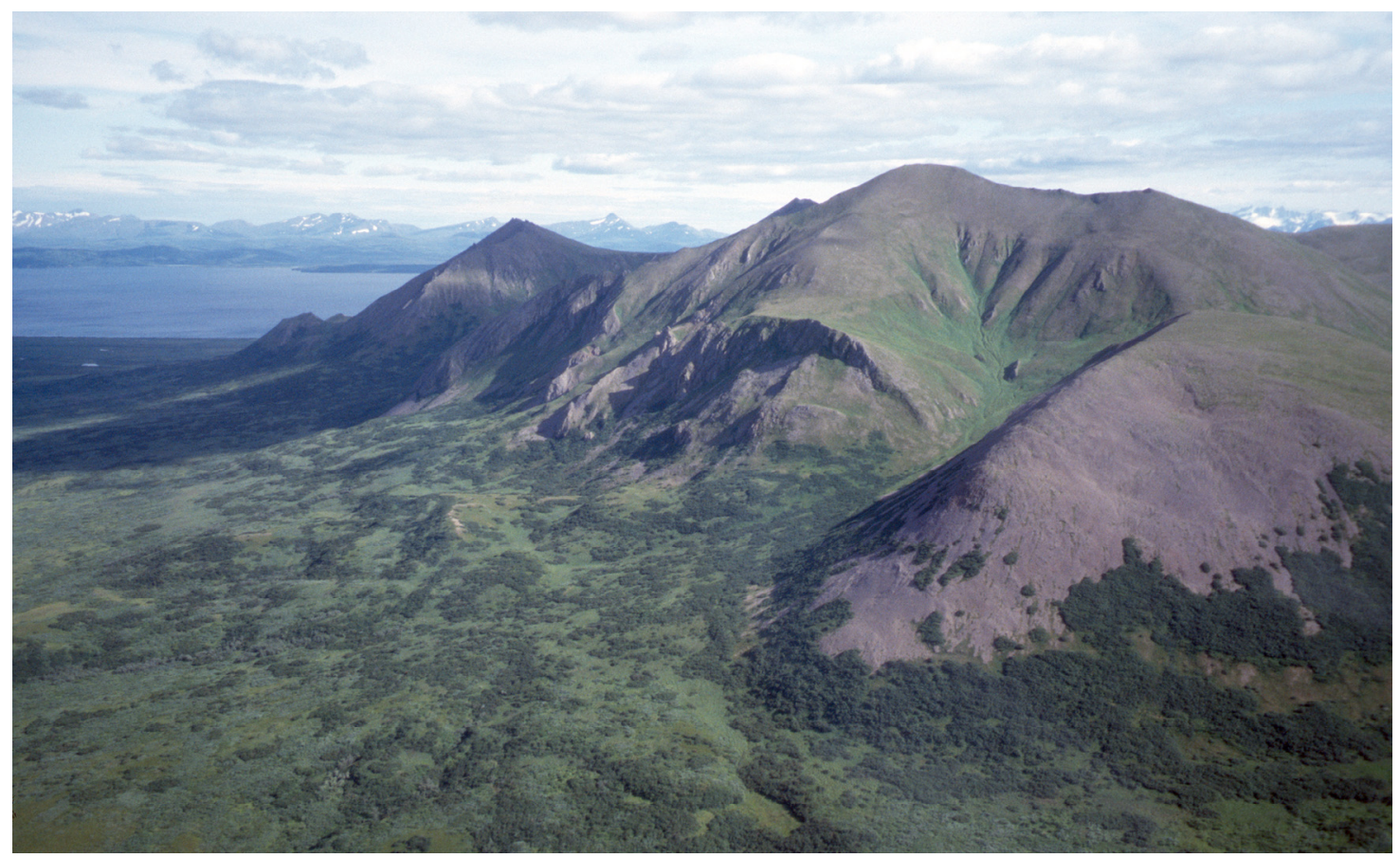

Figure 7. Northeast front of main Blue Mountain dome cluster (figs. 2,3A), viewed southeastward toward Upper Ugashik Lake. Landslide scarp scars small dome at center, above which rises central Dome 1776, highest in complex. Pyramidal peak at left is Dome 1572. In right foreground is crystal-poor Dome 1200. 

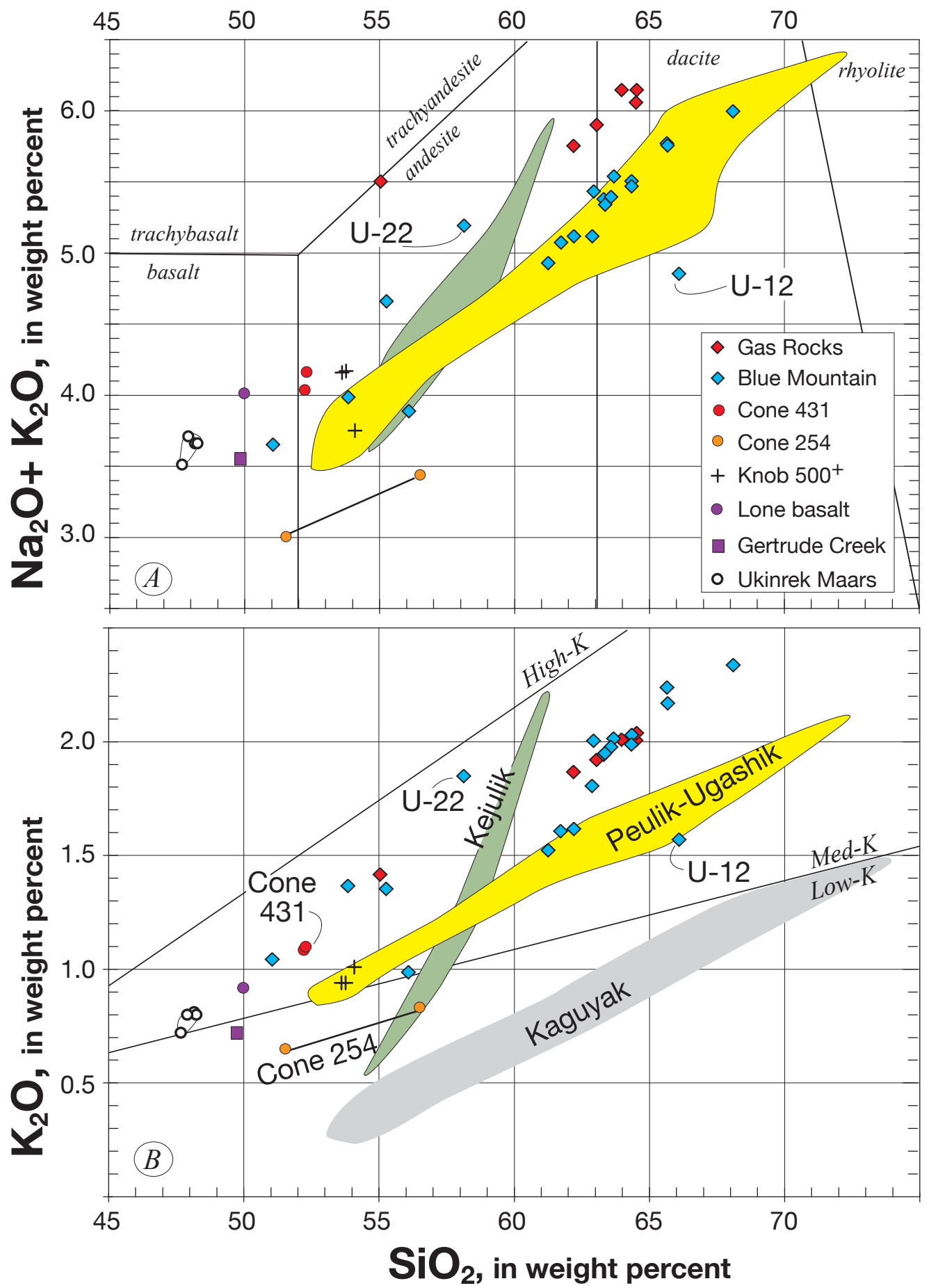

Figure 8. Chemical variations in samples from The Gas Rocks, Blue Mountain, and six nearby mafic units, as identified in inset. For comparison, shown selectively are fields for the nearby PeulikUgashik edifice (Miller, 2004), Kejulik Volcano (Kienle and others, 1983), and the low-K Kaguyak dome cluster and ignimbrite (Fierstein and Hildreth, in press). $A$, Total alkalies versus silica contents; nomenclature boundaries after $\mathrm{Le} B$ as and others (1986). $B, \mathrm{~K}_{2} \mathrm{O}$ versus $\mathrm{SiO}_{2}$ contents. $C, \mathrm{Fe} 0^{*} / \mathrm{MgO}$ versus $\mathrm{SiO}_{2}$ contents, where $\mathrm{FeO}{ }^{*}$ is total $\mathrm{Fe}$ calculated as $\mathrm{FeO}$. TH/CA is conventional field boundary between tholeiitic and calc-alkaline suites. $\mathrm{D}, \mathrm{CaO}$ and total alkalies versus $\mathrm{SiO}_{2}$ contents; alkalilime index (after Peacock, 1931) is $\mathrm{SiO}_{2}$ value at intersection of arrays. With indices $>61$, all suites are calcic, those of Blue Mountain and Peulik-Ugashik are $\sim 64$, and that of The Gas Rocks $\sim 62$. 


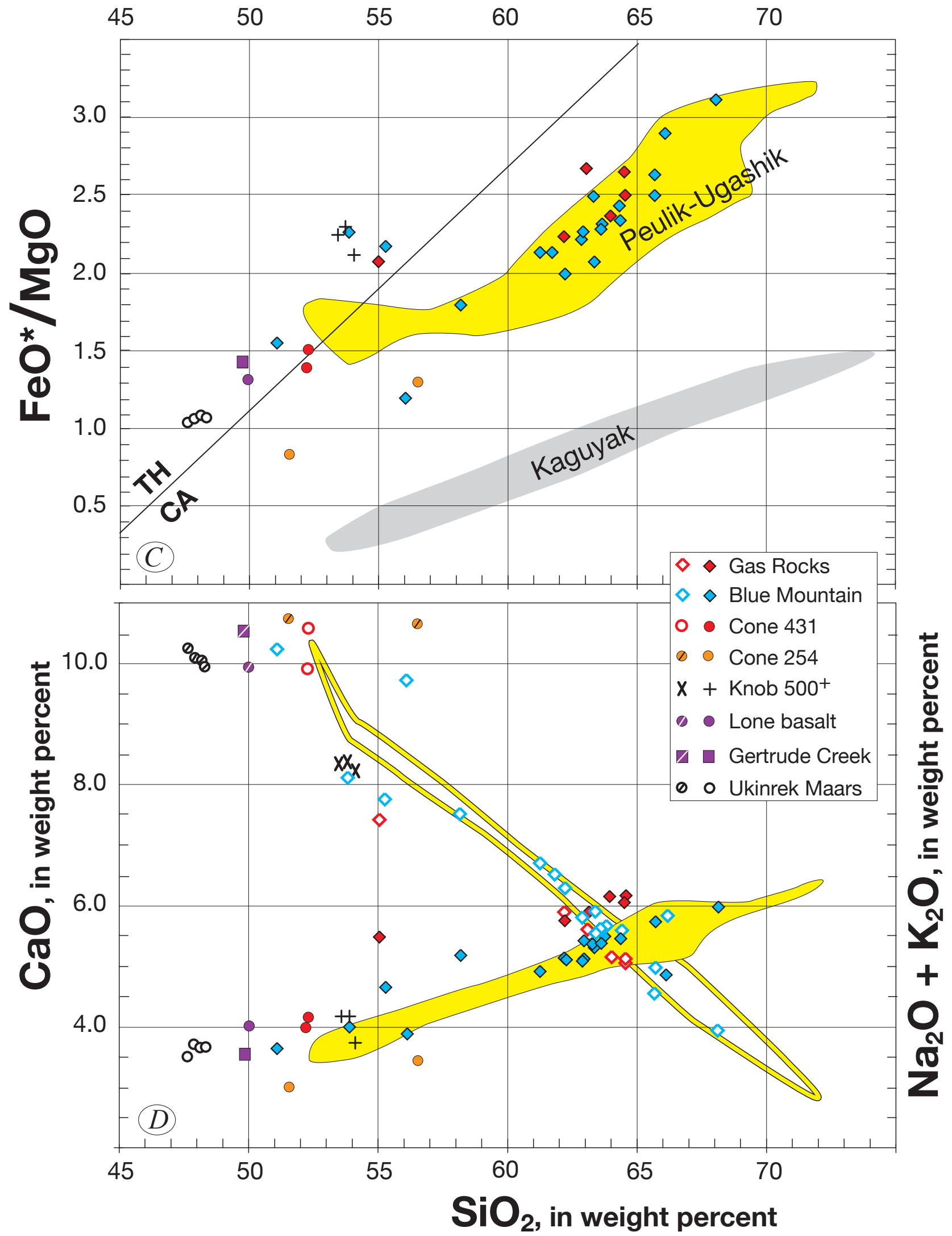

Figure 8.-Continued. 
Table 1. Chemical analyses of samples of eruptive products from Blue Mountain and The Gas Rocks.

[Major-element-oxide contents, normalized to $\mathrm{H}_{2} \mathrm{O}$-free totals of 99.6 weight percent (allowing 0.4 weight percent to account for trace oxides and halogens), determined by wavelength-dispersive $\mathrm{X}$-ray-fluorescence (XRF) analysis; trace-element contents determined by energy-dispersive XRF analysis. All samples analyzed at the U.S. Geological Survey laboratory in Lakewood, Colo.; analyst, D.F. Siems. Precision and accuracy were discussed by Bacon and Druitt (1988) and Siems (2000). FeO*, total Fe calculated as FeO; original total, volatile-free sum of major oxides (in weight percent) before normalization, with total Fe calculated as $\mathrm{Fe}_{2} \mathrm{O}_{3}$; LOI, loss on ignition at $900^{\circ} \mathrm{C}$ (in weight percent). Suffix "-i" on sample number denotes enclave enclosed in host lava. See figure 3 for sample locations]

\begin{tabular}{|c|c|c|c|c|c|c|c|c|c|c|c|c|c|c|c|c|c|c|c|c|c|c|c|}
\hline \multirow{2}{*}{ Sample } & \multicolumn{12}{|c|}{ Major-element oxides (weight percent) } & \multicolumn{10}{|c|}{ Trace elements (parts per million) } & \multirow[b]{2}{*}{ Description } \\
\hline & $\mathrm{SiO}_{2}$ & $\mathrm{TiO}_{2}$ & $\mathrm{Al}_{2} \mathrm{O}_{3}$ & $\mathrm{FeO} *$ & $\mathrm{MnO}$ & $\mathrm{MgO}$ & $\mathrm{CaO}$ & $\mathrm{Na}_{2} \mathrm{O}$ & $\mathrm{K}_{2} \mathrm{O}$ & $\mathrm{P}_{2} \mathrm{O}_{5}$ & LOI & $\begin{array}{c}\text { Original } \\
\text { total }\end{array}$ & $\mathrm{Rb}$ & $\mathrm{Sr}$ & Y & $\mathrm{Zr}$ & $\mathrm{Nb}$ & $\mathrm{Ba}$ & $\mathrm{Ni}$ & $\mathrm{Cu}$ & $\mathrm{Zn}$ & $\mathrm{Cr}$ & \\
\hline \multicolumn{24}{|c|}{ The Gas Rocks } \\
\hline $\mathrm{U}-1$ & 64.41 & 0.50 & 16.93 & 4.56 & 0.12 & 1.72 & 5.12 & 4.05 & 2.01 & 0.17 & 0.48 & 98.81 & 54 & 412 & 19 & 151 & 7 & 826 & 9 & 17 & 44 & 10 & North Point Dome \\
\hline $\mathrm{U}-2$ & 63.04 & 0.56 & 17.18 & 5.10 & 0.13 & 1.91 & 5.61 & 3.98 & 1.92 & 0.17 & 1.53 & 98.58 & 51 & 422 & 20 & 155 & 8 & 777 & 11 & 22 & 47 & 9 & SE face of NW Dome 600 \\
\hline $\mathrm{U}-3$ & 62.18 & 0.60 & 17.16 & 5.32 & 0.15 & 2.39 & 5.87 & 3.89 & 1.87 & 0.17 & 1.21 & 98.66 & 49 & 414 & 18 & 139 & 7 & 759 & 14 & 7 & 55 & 8 & NW face of SE Dome 700 \\
\hline U-5 & 64.49 & 0.49 & 16.85 & 4.43 & 0.14 & 1.78 & 5.09 & 4.11 & 2.04 & 0.18 & 0.74 & 98.69 & 56 & 402 & 17 & 155 & 7 & 843 & 11 & 7 & 44 & 9 & E face of SE Dome 700 \\
\hline $\mathrm{U}-5-\mathrm{i}$ & 55.04 & 0.93 & 18.72 & 7.78 & 0.26 & 3.75 & 7.41 & 4.09 & 1.42 & 0.20 & 0.86 & 98.44 & 36 & 501 & 35 & 108 & 8 & 840 & 18 & 20 & 68 & 14 & Mafic enclave in dacite of sample U-5 \\
\hline $\mathrm{K}-2689$ & 63.96 & 0.51 & 16.77 & 4.74 & 0.14 & 2.00 & 5.17 & 4.14 & 2.01 & 0.16 & 0.37 & 99.19 & 55 & 414 & 17 & 150 & 7 & 814 & 9 & 10 & 50 & 9 & Top of SE Dome 700 \\
\hline $\mathrm{U}-4$ & 52.23 & 0.98 & 17.20 & 8. & 0.17 & 6.20 & 9.91 & 2.95 & 1.08 & 0.23 & 3.70 & $\begin{array}{c}\text { Cone } \\
95.54\end{array}$ & $\frac{31}{22}$ & 7 & 19 & 111 & 6 & 36 & 26 & 55 & 70 & 63 & er clast \\
\hline $\mathrm{K}-2690$ & 52.29 & 0.98 & 17.33 & 8.34 & 0.17 & 5.55 & 10.55 & 3.06 & 1.10 & 0.22 & 4.93 & 94.28 & 23 & 469 & 20 & 110 & 6 & 397 & 64 & 57 & 79 & 339 & Ejecta Cone 431, bomb on S rim \\
\hline $\mathrm{U}-7 \mathrm{~A}$ & 56.51 & 0.91 & 16.74 & 6.26 & 0.13 & \multicolumn{18}{|c|}{ Cone 254} \\
\hline U-7B & 51.54 & 0.87 & 15.93 & 7.82 & 0.18 & 9.38 & 10.75 & 2.35 & 0.65 & 0.12 & 1.01 & 98.17 & 13 & 291 & 19 & 65 & 4 & 233 & 222 & 67 & 60 & 818 & Rocks: two scoria bombs \\
\hline \multicolumn{23}{|c|}{ Blue Mountain } & \\
\hline U-9 & 61.25 & 0.60 & 17.38 & 5.73 & 0.13 & 2.69 & 6.70 & 3.40 & 1.52 & 0.19 & 1.75 & 97.41 & 35 & 523 & 18 & 125 & 6 & 682 & 28 & 24 & 54 & 50 & Dome 971 , low on W slope \\
\hline U-9-i & 56.08 & 0.99 & 18.93 & 5.26 & 0.15 & 4.39 & 9.73 & 2.90 & 0.99 & 0.18 & 1.75 & 97.85 & 23 & 556 & 22 & 93 & 5 & 512 & 22 & 54 & 80 & 38 & Fine-grained enclave in sample U-9 \\
\hline $\mathrm{U}-10$ & 63.31 & 0.59 & 17.18 & 4.95 & 0.10 & 1.98 & 5.92 & 3.44 & 1.94 & 0.18 & 1.82 & 97.39 & 47 & 487 & 22 & 111 & 8 & 835 & 12 & 28 & 51 & 22 & Dome $700, \mathrm{E}$ face \\
\hline $\mathrm{U}-11$ & 63.68 & 0.55 & 16.60 & 5.09 & 0.13 & 2.20 & 5.64 & 3.52 & 2.01 & 0.18 & 1.09 & 98.38 & 50 & 474 & 15 & 105 & 7 & 841 & 13 & 25 & 50 & 18 & Dome $1776, \mathrm{~N}$ slope of W lobe \\
\hline $\mathrm{U}-12$ & 66.09 & 0.48 & 17.04 & 3.74 & 0.11 & 1.29 & 5.83 & 3.28 & 1.57 & 0.17 & 3.60 & 95.85 & 34 & 562 & 17 & 121 & 8 & 924 & 14 & 21 & 60 & 13 & 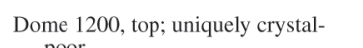 \\
\hline $\mathrm{U}-13$ & 62.94 & 0.59 & 16.70 & 5.39 & 0.14 & 2.39 & 5.84 & 3.43 & 2.00 & 0.18 & 0.80 & 98.43 & 50 & 471 & 20 & 114 & 9 & 847 & 11 & 28 & 53 & 14 & $\begin{array}{l}\text { saddle between Domes } 1600 \\
776\end{array}$ \\
\hline U-14 & 61.72 & 0.59 & 17.39 & 5.43 & 0.13 & 2.55 & 6.53 & 3.47 & 1.61 & 0.19 & 0.79 & 97.96 & 36 & 535 & 14 & 122 & 7 & 690 & 17 & 26 & 49 & 21 & Dome 1600, steep SSE face \\
\hline U-16 & 63.57 & 0.57 & 16.43 & 5.35 & 0.14 & 2.34 & 5.63 & 3.42 & 1.98 & 0.18 & 0.70 & 98.23 & 49 & 460 & 17 & 109 & 7 & 824 & 13 & 65 & 53 & 18 & $\mathrm{SW}$ ridge, $\mathrm{S}$ rim, breccia \\
\hline $\mathrm{U}-17$ & 64.34 & 0.54 & 16.36 & 4.92 & 0.14 & 2.11 & 5.53 & 3.47 & 2.03 & 0.16 & 0.34 & 98.61 & 50 & 464 & 21 & 113 & 8 & 853 & 12 & 27 & 48 & 14 & SW ridge, hilltop near nose \\
\hline $\mathrm{U}-17-\mathrm{i}$ & 51.05 & 1.07 & 16.98 & 9.86 & 0.19 & 6.35 & 10.23 & 2.61 & 1.04 & 0.20 & 1.19 & 97.36 & 18 & 536 & 18 & 72 & 3 & 339 & 25 & 61 & 89 & 94 & Fine-grained enclave in sample U-17 \\
\hline U-18 & 64.33 & 0.51 & 16.44 & 4.92 & 0.14 & 2.02 & 5.61 & 3.48 & 1.99 & 0.16 & 0.96 & 98.16 & 49 & 461 & 16 & 110 & 8 & 846 & 12 & 31 & 43 & 21 & Central ridge, $S$ end, dome breccia \\
\hline U-19 & 62.88 & 0.56 & 17.03 & 5.43 & 0.14 & 2.44 & 5.84 & 3.31 & 1.81 & 0.15 & 1.74 & 97.09 & 47 & 455 & 15 & 107 & 8 & 834 & 11 & 24 & 52 & 17 & SSW ridge, top of nose 1400 \\
\hline U-20 & 68.09 & 0.37 & 16.36 & 3.45 & 0.12 & 1.11 & 3.95 & 3.66 & 2.34 & 0.15 & 1.24 & 98.00 & 58 & 420 & 15 & 121 & 9 & 1,040 & 10 & 7 & 35 & 7 & Dome $1572, \mathrm{SW}$ face \\
\hline $\mathrm{U}-20-\mathrm{i}$ & 55.26 & 0.89 & 19.13 & 7.86 & 0.16 & 3.63 & 7.74 & 3.31 & 1.35 & 0.26 & 1.34 & 97.87 & 29 & 474 & 20 & 110 & 6 & 554 & 16 & 35 & 63 & $<5$ & Fine-grained enclave in sample $\mathrm{U}-20$ \\
\hline $\mathrm{U}-21$ & 65.64 & 0.49 & 16.69 & 4.44 & 0.13 & 1.69 & 4.56 & 3.53 & 2.24 & 0.18 & 1.26 & 97.87 & 56 & 432 & 15 & 111 & 8 & 968 & 13 & 22 & 45 & 8 & Dome 1700, SE nose \\
\hline $\mathrm{U}-21-\mathrm{i}$ & 53.84 & 0.99 & 18.64 & 9.43 & 0.19 & 4.17 & 8.14 & 2.62 & 1.37 & 0.22 & 2.60 & 96.19 & 30 & 537 & 19 & 88 & 6 & 447 & 15 & 144 & 75 & 6 & Fine-grained enclave in sample $\mathbf{U}-21$ \\
\hline $\mathrm{U}-22$ & 58.13 & 0.72 & 17.68 & 6.36 & 0.15 & 3.56 & 7.49 & 3.34 & 1.85 & 0.32 & 0.71 & 98.01 & 45 & 772 & 23 & 167 & 7 & 907 & 21 & 34 & 62 & 26 & Dome 1151, top \\
\hline U-23 & 65.68 & 0.47 & 16.42 & 4.28 & 0.14 & 1.71 & 4.98 & 3.59 & 2.17 & 0.17 & 0.59 & 98.27 & 54 & 454 & 15 & 114 & 9 & 971 & 7 & 18 & 42 & 10 & Dome $1100, \mathrm{SW}$ rim \\
\hline $\mathrm{K}-2693$ & 63.36 & 0.58 & 16.70 & 5.28 & 0.11 & 2.55 & 5.56 & 3.39 & 1.95 & 0.12 & 3.28 & 96.05 & 46 & 471 & 13 & 89 & 7 & 755 & 10 & 24 & 53 & 27 & Dome 1776 , top \\
\hline
\end{tabular}




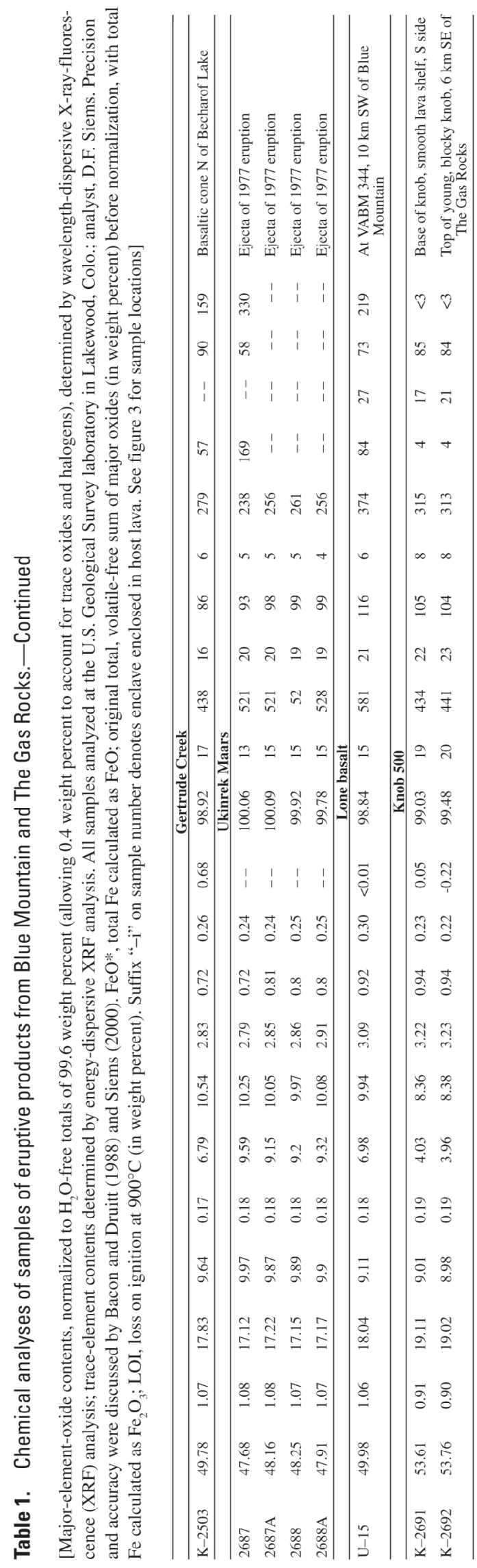

toward Bristol Bay (figs. 1, 2). In the protective shadow of the Blue Mountain edifice, a narrow moraine, as much as $150 \mathrm{~m}$ high, extends $7 \mathrm{~km}$ northwestward from Dome 1600 (fig. 3A). A lower but parallel moraine extends northwestward in the lee of the northerly dome cluster, and a subdued recessional moraine loop connects the two ridges (fig. 3). Stones in the till are predominantly subangular to subrounded slabs and blocks (max $1 \mathrm{~m}$ diam) of Blue Mountain dacite but include abundant granitoids, sandstone, conglomerate, and altered green volcanic rocks of intermediate composition, evidently derived from the highlands southeast of the Ugashik Lakes.

Present-day volumes of the Blue Mountain domes have been estimated, recognizing that at least 20 percent of the initial lavas, and a completely unknown pyroclastic volume, have been glacially eroded away. The noncontiguous northern cluster of three small domes totals $\sim 60$ million $\mathrm{m}^{3}$ in volume. The central mass of the main cluster, including Domes 1776 and 1700 (fig. $3 A$ ), totals $\sim 500$ million $\mathrm{m}^{3}$ in volume, and its satellites' volumes are estimated as follows: easterly Dome $1572, \sim 180$ million $\mathrm{m}^{3}$; the three small southerly domes, 35 to 45 million $\mathrm{m}^{3}$ each; westerly Dome 1600, 160 million $\mathrm{m}^{3}$; and crystal-poor northerly Dome 1200, 35 million $\mathrm{m}^{3}$. These estimates provide a total surviving volume of $1.05 \mathrm{~km}^{3}$ of Blue Mountain dacite.

\section{Lone Basaltic Outlier}

About $10 \mathrm{~km}$ southwest of Blue Mountain, an isolated 0.38- $\mathrm{km}^{2}$-area exposure of olivine-basaltic lava (50 weight percent $\mathrm{SiO}_{2}, 7$ weight percent $\mathrm{MgO}$ ) forms a subdued, glacially scoured ridge (Lone basalt, fig. 2) that rises $80 \mathrm{~m}$ above the surrounding muskeg (fig. 2). The rock contains 5 to 8 volume percent olivine phenocrysts $(0.5-2 \mathrm{~mm}$ diam) and sparse oxide microphenocrysts in a holocrystalline groundmass of intergrown plagioclase laths and equant grains of olivine, oxides, and rare clinopyroxene. This subalkaline basalt is similar to, but not quite as primitive as, the basalt of Ukinrek Maars (fig. 8; table 1). It differs compositionally, however, from the mafic rocks of nearby Mount Peulik (fig. 8; Miller, 2004) and from those of the other arc-front centers nearby, and it is not demonstrably related to Blue Mountain dacite. Nonetheless, the composition of the Lone basalt is not far from that of the mafic enclaves in Blue Mountain dacite, nor from that of the 500-ka subalkaline basaltic cone at Gertrude Creek northeast of Becharof Lake (figs. 2, 8). Wilson and Shew (1992) determined a whole-rock K-Ar age of $593 \pm 73 \mathrm{ka}$ for the Lone basalt.

We note that if a straight line were drawn on figure 2 connecting the Lone basalt with the basaltic cone at Gertrude Creek, it would transect both Blue Mountain and The Gas Rocks. Such a line, however, would diverge by about $20^{\circ}$ from the trace of the Bruin Bay Fault as projected beneath the lakes to its presumed extension near Ugashik Narrows (fig. 2), as inferred by Detterman and others (1987a). Because the sense 
Figure 9. ${ }^{40} \mathrm{Ar} /{ }^{39} \mathrm{Ar}$ age spectra with stacked $\mathrm{K} / \mathrm{Cl}, \mathrm{K} / \mathrm{Ca}$, and radiogenic yield plots, along with isotope-correlation (isochron) diagrams for samples from The Gas Rocks and Blue Mountain. Apparent ages, isotope-ratio boxes, interpreted ages (bold), and intercept ratios are all $\pm 1 \sigma$. Shaded boxes show heating steps (in degrees Celsius) used for age and isotope-ratio calculations.
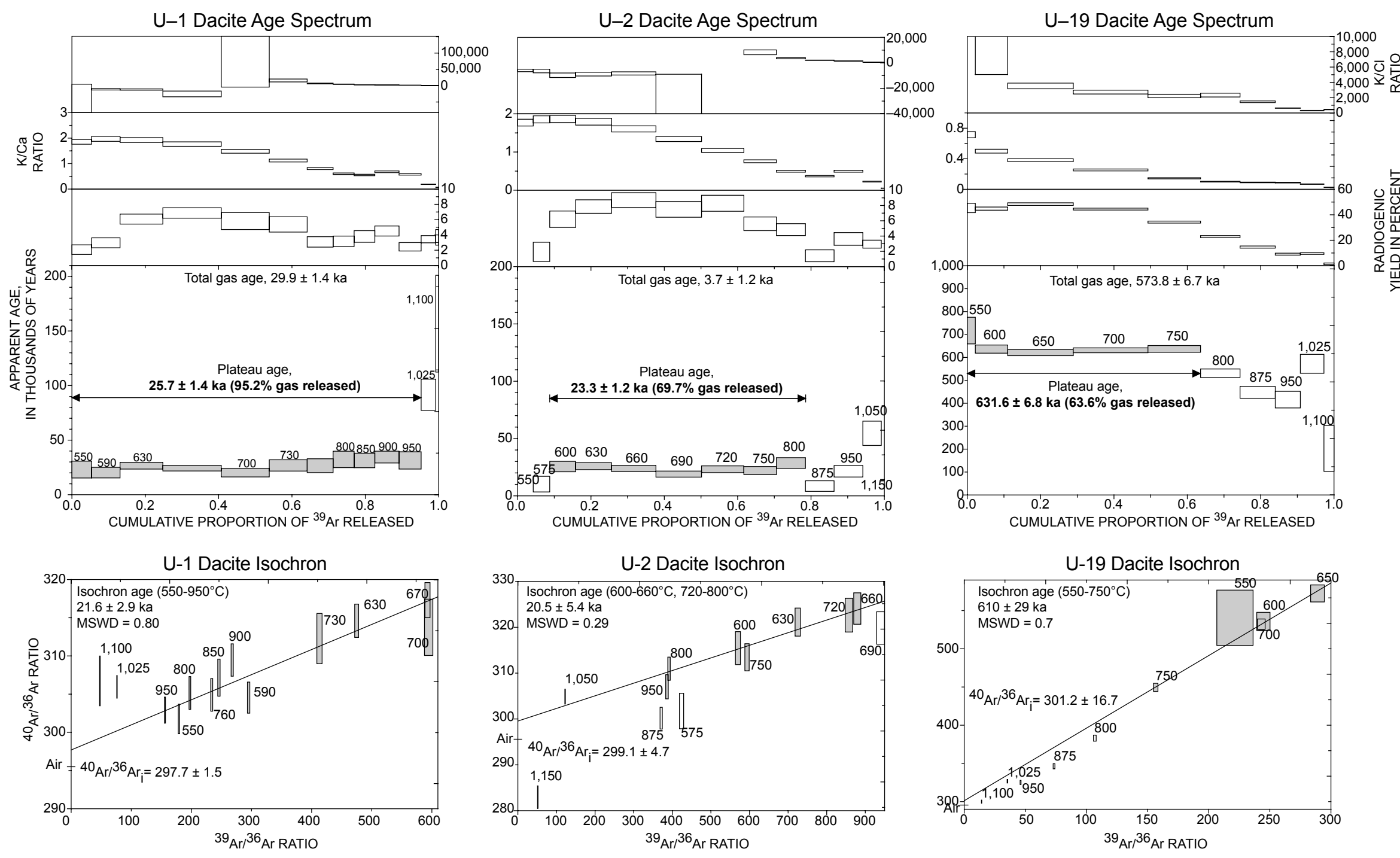
of displacement on the fault exposed north and south of Lower Ugashik Lake (fig. 2), however, is opposite to that everywhere else along the fault, this segment may be another fault entirely, and the real Bruin Bay Fault, concealed by glacial deposits and thick Tertiary sedimentary rocks (MacNeal and others, 1961), may actually continue southwestward from The Gas Rocks to Blue Mountain and the Lone basalt, instead of veering southward down the Ugashik Lakes basin (fig. 2).

\section{Basalt of Gertrude Creek}

The basalt of Gertrude Creek makes up a 1-km-wide remnant of an ejecta cone and lava-flow apron that form a glacially smoothed domical swell $\sim 5 \mathrm{~km}$ northeast of Becharof Lake (fig. 2), near the trace of the Bruin Bay Fault (Riehle and others, 1993; Hildreth and others, 2003, 2004). The surviving outcrop has $\sim 60 \mathrm{~m}$ of gentle relief and includes a 200-m-wide degraded crater, now only 5 to $8 \mathrm{~m}$ deep, rimmed by brick-red scoria blocks and sheets of blobby agglutinate that are broken and frost heaved into slabs. Outside the rim is a frost-disrupted apron of blocks and slabs of dark-gray, massive to finely vesicular basaltic lava. The subalkaline high-alumina basalt (49.8 weight percent $\mathrm{SiO}_{2}, 17.8$ weight percent $\mathrm{Al}_{2} \mathrm{O}_{3}, 6.8$ weight percent $\mathrm{MgO}$, table 1) contains abundant small phenocrysts of olivine, clinopyroxene, and plagioclase and inclusions (in olivine) of Cr-rich spinel. A slab of holocrystalline lava yielded an ${ }^{40} \mathrm{Ar} /{ }^{39} \mathrm{Ar}$ plateau age of $500 \pm 14 \mathrm{ka}$ (Hildreth and others, 2003), not much younger than the age of the Lone basalt $(593 \pm 73 \mathrm{ka})$.

\section{Basalt of Ukinrek Maars}

Also near the projected trace of the (locally concealed) Bruin Bay Fault, the basalt of Ukinrek Maars was erupted over 11 days in 1977, only $2 \mathrm{~km}$ from the shore of Becharof Lake (figs. 2, 3; Detterman and others, 1987a). A multipulse eruptive sequence (Kienle and others, 1980) produced two steepwalled craters (400 m apart), an apron of stratified ejecta, and a lava-spatter mound on the floor of one crater. Although fine ash was recorded as far as $160 \mathrm{~km}$ east of the vent, the peripheral apron of ejecta thins from as much as $26 \mathrm{~m}$ at the crater rim to only $2 \mathrm{~cm}$ at a radial distance of $3 \mathrm{~km}$ (Self and others, 1980). Proximally, the dozens of strata range from laminae to beds as much as $40 \mathrm{~cm}$ thick, which include ash-and-lapilli falls, surges, and ballistic-block-fall deposits. Activity was predominantly phreatomagmatic but included strombolian scoria falls (Ort and others, 2000). Juvenile ejecta ranges in texture from highly vesicular and ragged scoriae to cauliflower and rounded dense clasts; all samples analyzed are composed of transitional olivine basalt (48 weight percent $\mathrm{SiO}_{2}$, fig. 8). Eruptive products contain olivine and small plagioclase phenocrysts, sparse clinopyroxene, and inclusions of $\mathrm{Cr}$-spinel in olivine. All the deposits are rich in lithic clasts derived from till and bedrock, which are exposed in the crater walls. Excavation of the two craters, 170 and $300 \mathrm{~m}$ wide, provided about 4.3 million $\mathrm{m}^{3}$ of lithic debris (Kienle and others, 1980), a volume greater than the dense-rock-equivalent volume of juvenile ejecta estimated by Self and others (1980). The volume of the spatter mound, now lake covered on the floor of the larger crater, was estimated at nearly 1 million $\mathrm{m}^{3}$.

\section{Basaltic Andesite of Knob 500}

About $5 \mathrm{~km}$ east of the Ukinrek Maars, a circular mesa (fig. 2) of postglacial mafic lava (53.6-54.1 weight percent $\left.\mathrm{SiO}_{2}\right), \sim 1 \mathrm{~km}$ in diameter, stands $100 \mathrm{~m}$ above a surrounding hummocky lowland that consists of lake deposits and a debrisavalanche sheet derived from the Ugashik-Peulik edifice. The rugged surface of the mesa, corrugated by several pressure ridges, has not been overridden by either ice or avalanche, and the lava appears to have welled up in place and spread out locally, as if confined. The unit is compositionally similar to the postglacial lava flows that make up the cone and apron of Mount Peulik (Miller, 2004), but is distinguishable from all other units in the district (fig. 8). This enigmatic exposure may represent an authentic flank vent for Peulik magma or, conceivably, a rootless secondary vent for invasive lava that had burrowed beneath the avalanche deposit.

\section{The Gas Rocks Dacite Domes}

The Gas Rocks cluster consists of three dacite domes and one stratified fragmental mafic cone (fig. 3B). A second mafic cone (Cone 254) is exposed in a lakeshore bluff $4 \mathrm{~km}$ due west of The Gas Rocks. Viewed from a distance (fig. 10), the three high knobs that make up The Gas Rocks include two of the domes and mafic Cone 431 (the southeasternmost knob).

The third dacite dome is much lower, standing only $\sim 45 \mathrm{~m}$ above the lake on the north point of the Gas Rocks peninsula (figs. 10, 11). Separated by a linear trough from the much higher adjacent dome, North Point Dome appears to be an independent extrusion rather than a thick coulee issuing from its neighbor, an inference supported by its slightly more evolved composition (table 1). The larger domes, Domes 600 and 700 (figs. 10, 12), have 180 and 210 $\mathrm{m}$ relief, respectively, above the lake. Dome 600 appears to be a single simple extrusion, as shown by the steep jointing that flares slightly outward toward the top of its northeast face (fig. 13). Nonetheless, a pair of lava flows, each 10 to $15 \mathrm{~m}$ thick, extends to the shoreline from the foot of that face (fig. 13). In common with a lava flow associated with North Point Dome (fig. 11), these flows have been truncated and thinned by the ice that flowed northwestward down the lake basin. Dome 700 likewise has steep jointing on its sheer 


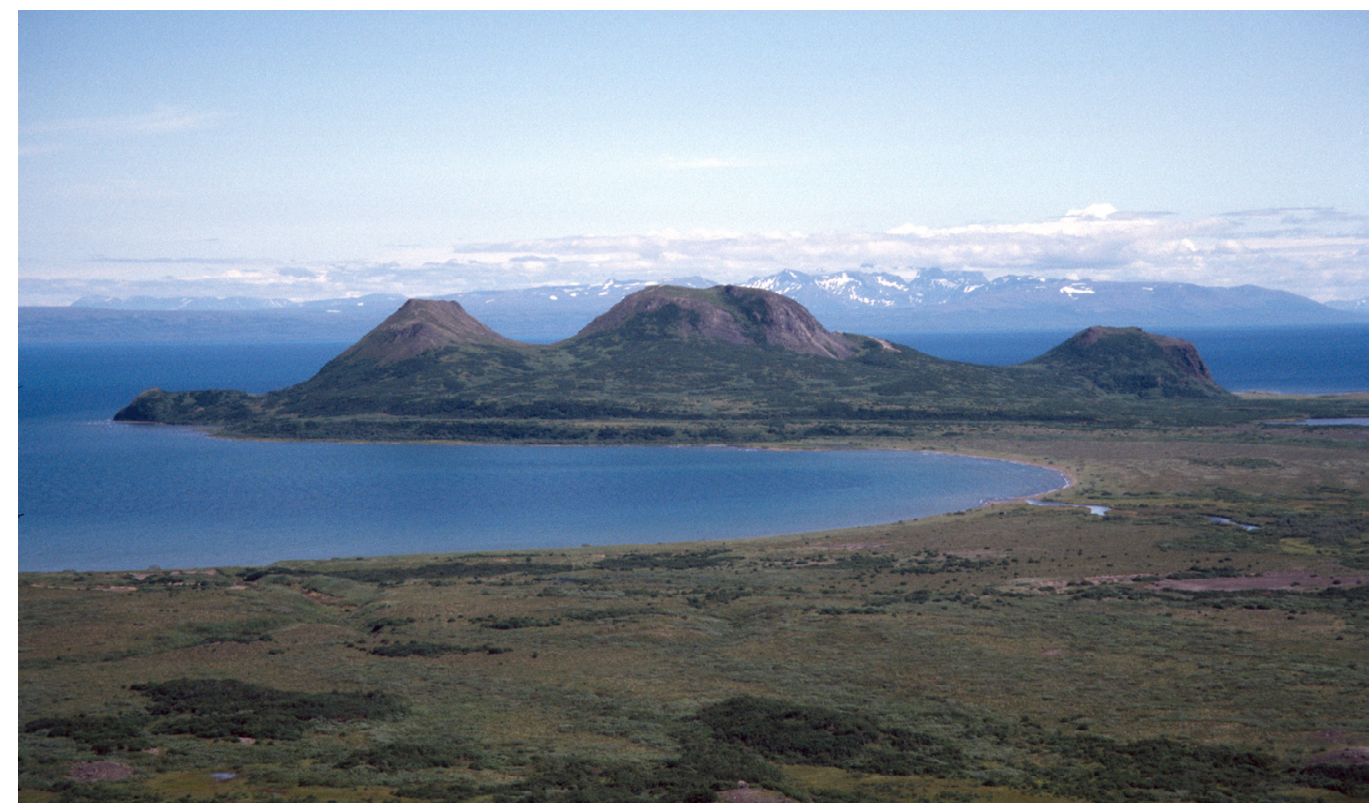

Figure 10. The Gas Rocks on Becharof Lake (figs. 2,3B) viewed east-northeastward. From left to right are low North Point Dome, flat-topped Dome 600, rounded Dome 700, and mafic ejecta Cone 431, standing, respectively, about $45,180,210$, and $120 \mathrm{~m}$ above lake level. Vegetated apron around the knolls consists of colluvial, glacial, and beach deposits, marked by a wave-cut strandline bench 25 to $30 \mathrm{~m}$ above present lake level. Small barren ridgecrest just to right of highest knoll is a curvilinear exposure of well-rounded pebble-cobble gravel, possibly an esker remnant. Beyond lake, skyline highland is glacially eroded Kejulik Volcano, resting on Mesozoic sedimentary rocks.

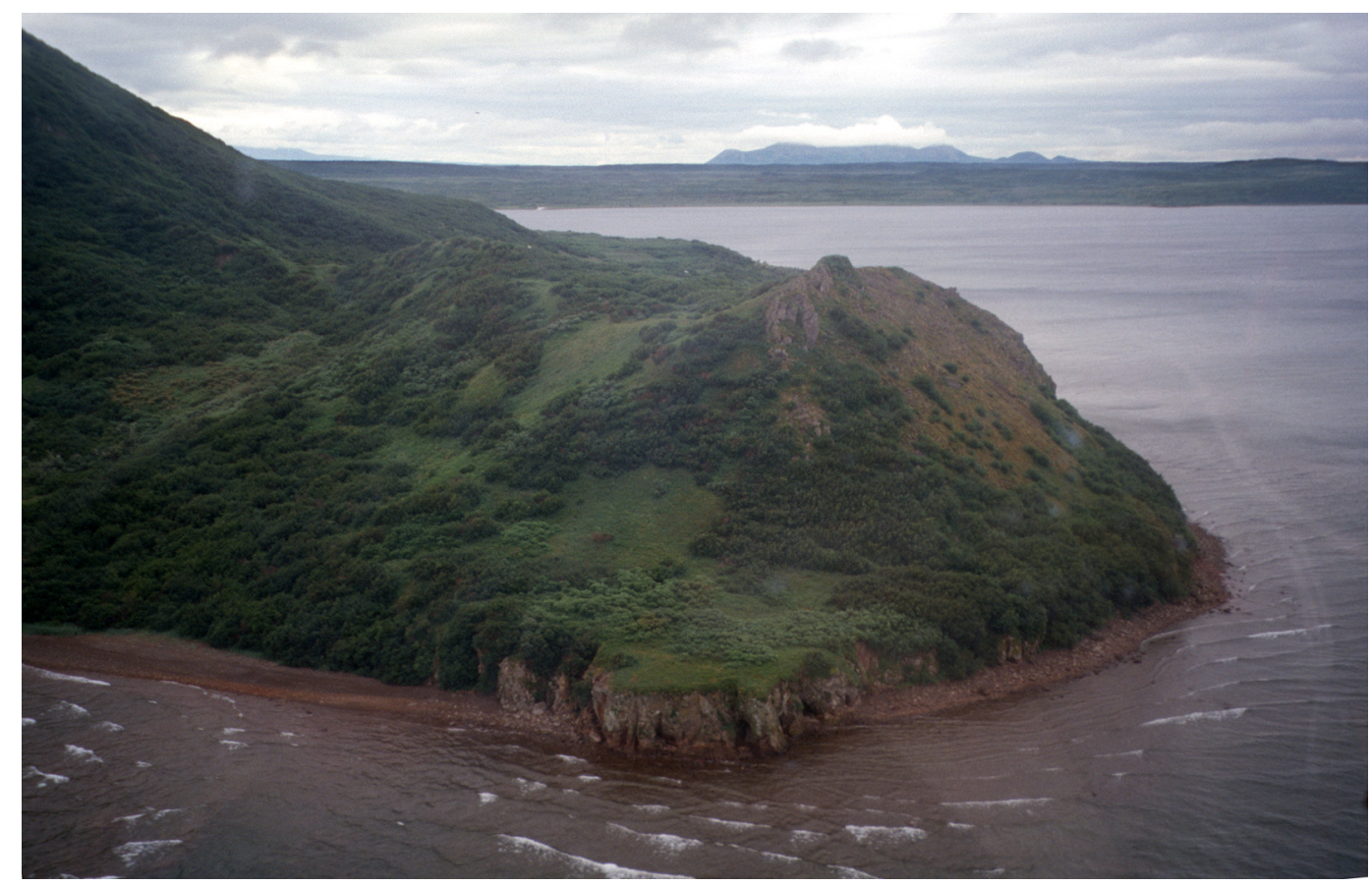

Figure 11. Small, glacially eroded North Point Dome at The Gas Rocks (fig. 3B). Reaching only $150 \mathrm{ft}$ (45 $\mathrm{m})$ above lake level, dome rises above a foreground lava flow (probably coeruptive) and is separated by a low trough from steeper Dome 600 at left. View southwestward, with Blue Mountain on the horizon. 
east face, but the moderately dipping sheeting on its west slope suggests serial extrusion of a few exogenous lobes (fig. 14). Little or no glassy or pumiceous carapace remains on any of the domes, which were all completely submerged and scoured by glacial ice. The deep interior exposure on the steep northeast faces of the two highest domes owes to enhanced erosion by the principal glacial lobe that flowed northwestward toward Bristol Bay.

All three domes consist of phenocryst-rich dacite (62.264.5 weight percent $\mathrm{SiO}_{2}$, fig. 8; table 1). The five samples analyzed all contain 25 to 30 volume percent phenocrysts, dominated by plagioclase but including several volume percent each of biotite and amphibole and 1 to 2 volume percent each of quartz and Fe-Ti oxides. Most of the plagioclase is twinned and zoned, euhedral to subhedral, and either solitary or in multicrystalline intergrowths, 2 to $6 \mathrm{~mm}$ across. Only a few plagioclase phenocrysts are sieve textured, either anhedral and extensively sieved or subhedral with thin, finely sieved zones that lie either slightly or far inboard of their clear rims. Biotite and amphibole are in nearly equal abundance and are generally oxidized, either foxy red or opacitized. Fe-Ti oxides occur as scattered microphenocrysts, and quartz as subhedral, but rounded (0.5-2 mm diam), unstrained free crystals. Some quartz grains contain glass (melt) inclusions, and some are either embayed or shattered. Groundmasses of all the dacites are finely microcrystalline and charged with numerous microlites and microphenocrysts of plagioclase, amphibole, biotite, and Fe-Ti oxides.

Fine-grained enclaves (1-25 cm diam) are common in all three domes; those examined consist of holocrystalline intergrowths of elongate $(0.5-1 \mathrm{~mm}$ diam $)$ plagioclase and amphibole with subordinate biotite and Fe-Ti oxides, as well as scattered plagioclase phenocrysts (1-3 mm diam) that probably originated in the host dacite. The one chemically analyzed enclave (from Dome 700; fig. 3B) contains 55 weight percent $\mathrm{SiO}_{2}$ (table 1). On the whole, the lithologic, chemical, and petrographic resemblances of The Gas Rocks dacites to (much older) Blue Mountain dacite are striking.

The volumes of the three dacite domes at The Gas Rocks, as exposed today from northwest to southeast, are estimated at 0.5 million, 15 million, and 20 million $\mathrm{m}^{3}$. At least half as much more rock is likely to have been removed from each dome by glacial erosion.

We determined two ${ }^{40} \mathrm{Ar} /{ }^{39} \mathrm{Ar}$ ages on groundmass concentrates from samples of The Gas Rocks dacite (fig. 9; table 2). Sample U-1, from the small North Point Dome (fig. $3 B$ ), yielded a weighted-mean plateau age of $25.7 \pm 1.4 \mathrm{ka}$, and sample U-2, from Dome 600, 23.3 $\pm 1.2 \mathrm{ka}$. At their extremes, the two error envelopes just overlap, although nothing on the ground is known to contradict a younger age for the larger dome. Because of their petrographic and compositional similarity, it cannot be excluded that the three domes are essentially contemporaneous, plausibly fed by a common dike, the northwesterly strike of which would be similar to the presentday plate-convergence direction (which might in turn influence the direction of maximum horizontal compression).

\section{Basalt of Cone 431}

The southeastern knob of The Gas Rocks (Cone 431, figs. $2,3 A$ ) is not a dome but a remnant of a basaltic ejecta cone that rises abruptly $120 \mathrm{~m}$ above the current lake level (fig. 14). The poorly sorted ejecta consists predominantly of lapilli $(1-10 \mathrm{~cm}$ diam) within a matrix of coarse ash (fig. 15), although bombs as big as $30 \mathrm{~cm}$ across are sparse. Stratification is dominantly planar, consisting of apparently massive lapilli-fall beds, several meters thick, separated by layers and lenses, 0.1 to $1 \mathrm{~m}$ thick, of coarse palagonitized ash. The massiveness of the thick layers belies patchy internal grain-size variations and locally discontinuous, vague bedding. Although the ash-rich partings indicate eruptive pulsation, no profound internal unconformity was observed that might suggest a significant break in the eruption. Layering generally dips gently away from the lake, suggesting that the vent lay where the lake is today, consistent with the absence of coarse proximal ejecta in the surviving edifice. The volume of the cone remnant is $\sim 5$ million $\mathrm{m}^{3}$, but several times as much rock is likely to have been eroded away by the glacier that occupied the Becharof Lake basin.

Consistent with the poor sorting, poor stratification, and ash-rich interlayers, the limited vesicularity of the basaltic clasts suggests hydrovolcanic (phreatomagmatic) eruption. The lapilli and bombs are poorly to only moderately vesicular, characteristic of syneruptive interaction with water that aborts the degassing-inflation process by abruptly quenching the chilled pyroclasts. Secondary induration (including minor palagonitization) provided some strength to the edifice, but the pyroclasts had been deposited loose, after being chilled sufficiently to prevent the agglutination otherwise common to near-vent accumulation of mafic ejecta. The uniformly gentle planar dips of the bedding suggest that deposition was not subglacial or englacial but that the water involved in the eruption was either ground water or a shallow lake. In contrast to lithic-rich Ukinrek Maars ejecta, Cone 431 ejecta is poor in accidental lithic materials, indicating that the hydrovolcanic explosions did not mine down significantly into underlying glacial deposits or bedrock.

Pyroclasts from two different sites and layers proved to be compositionally similar, both containing 52.2 weight percent $\mathrm{SiO}_{2}$, 0.98 weight percent $\mathrm{TiO}_{2}$, and 1.1 weight percent $\mathrm{K}_{2} \mathrm{O}$ (fig. 8; table 1). Phenocryst contents total 10 to 12 volume percent, including abundant plagioclase, common olivine, sparse clinopyroxene, rare Fe-Ti oxides, and rare quartz xenocrysts with reaction rims. Many plagioclase crystals are anhedral and sieved internally but have clear overgrowths. The partially glassy groundmasses are choked with plagioclase microphenocrysts. Like the 1977 Ukinrek eruption, Cone 431 (fig. 3B) was probably fed by a small, fairly homogeneous batch of magma. Unlike the transitional basalt of Ukinrek Maars, however, the basalt of Cone 431 is clearly subalkaline and considerably less primitive, containing only 5.5 to 6.2 weight percent $\mathrm{MgO}$ (table 1). Figure 8 illustrates that, for many (but not all) elements, the basalt of Cone 431 plots more or less collinearly with The Gas Rocks dacites and with a mafic enclave in one of them, suggesting that the mafic and dacitic magmatism were nearly contemporaneous. 


\section{Basalt of Cone 254}

Another basaltic cone (Cone 254, figs. 2, 3B) is exposed in only two dimensions for $800 \mathrm{~m}$ along a lakeshore cliff $4 \mathrm{~km}$ west of The Gas Rocks. From the beach, the well-stratified exposure is 25 to $30 \mathrm{~m}$ high, overlain by $30 \mathrm{~m}$ of surficial deposits that culminate in Hill 254 (fig. 16). Ash-rich beds, 1 to $5 \mathrm{~cm}$ thick, alternate with ash-poor lapilli-fall layers that are mostly 5 to $40 \mathrm{~cm}$ thick (fig. 17) but include a few as much as 2 to $3 \mathrm{~m}$ thick high on the wall. The ash-rich layers and undulatory bedding in the lower part of the section probably reflect explosive hydrovolcanic-surge emplacement. The yellowbrown color and strong induration of much of the cliff section reflect weak palagonitization of the ash-grade component. The dominant lapilli are mostly 1 to $3 \mathrm{~cm}$ across, although a few thicker, coarser beds also contain clasts 10 to $15 \mathrm{~cm}$ across. Accidental lithic materials are common, including granitoids, sandstone, and various volcanic rocks, probably all derived from underlying glacial deposits. Bedding dips $15-20^{\circ}$ from the ends of the exposure inward toward its center, where apparent dips are subhorizontal but have a gentle component into the cliff, suggesting that the vent had been out under the present-day lake. The two-dimensional exposure precludes a meaningful volume estimate.

Juvenile clasts are phenocryst poor, containing 3 to 5 volume percent olivine (0.2-1.5 mm diam) but no oxides, pyroxene, or plagioclase phenocrysts. Quartz xenocrysts with reaction rims are sparsely present. Some of the ejecta is nonvesicular throughout, but most has dense cauliflower rinds and finely vesicular interiors, reflecting syneruptive hydrovolcanic chilling. The two bombs analyzed contain 51.5 and 56.5 weight percent $\mathrm{SiO}_{2}$ at 9.4 and 4.8 weight percent $\mathrm{MgO}$, respectively (table 1), and both are strongly subalkaline. Even the more evolved (or contaminated) sample is less alkalic and more calcic than the subalkaline basalt of nearby Cone 431 (figs. 2, $3 B, 8)$.

\section{Gas Discharge}

The earliest known map on which The Gas Rocks are so named was by Smith and Baker (1924), based on fieldwork in 1922. Although they did not discuss the gas discharge, it can plausibly be inferred from the placename alone that the phenomena had first been observed there no later than that year. Waring (1917) had earlier repeated a secondhand report of hot springs on the southwest shore of Becharof Lake, but he made no mention of either gas discharge or use of the placename. The principal manifestations observed in the interval 1977-2004 (Barnes and McCoy, 1979; Motyka and others, 1993; Symonds and others, 1997; Evans and others, 2007) were (1) as many as three vigorous upwellings of cold lakewater charged with abundant $\mathrm{CO}_{2}$ bubbles (fig. 18) a few tens of meters offshore from the northeast side of The

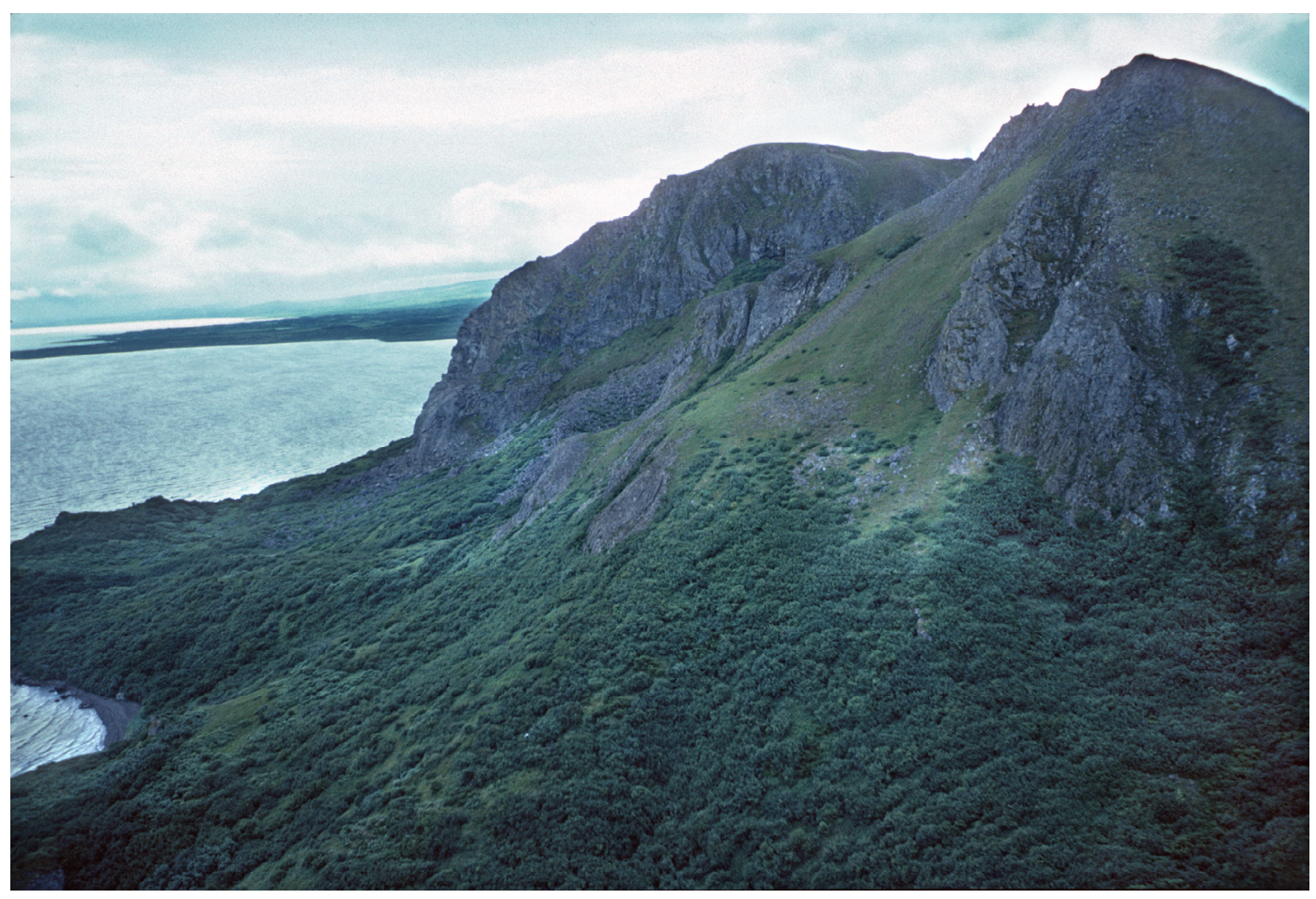

Figure 12. Steep northeast faces of Domes 600 (right) and 700 (center) at The Gas Rocks (fig. 3B), viewed southeastward, showing truncation of domes by glacial erosion and, below, brush-covered fan of postglacial talus and landslide masses. 


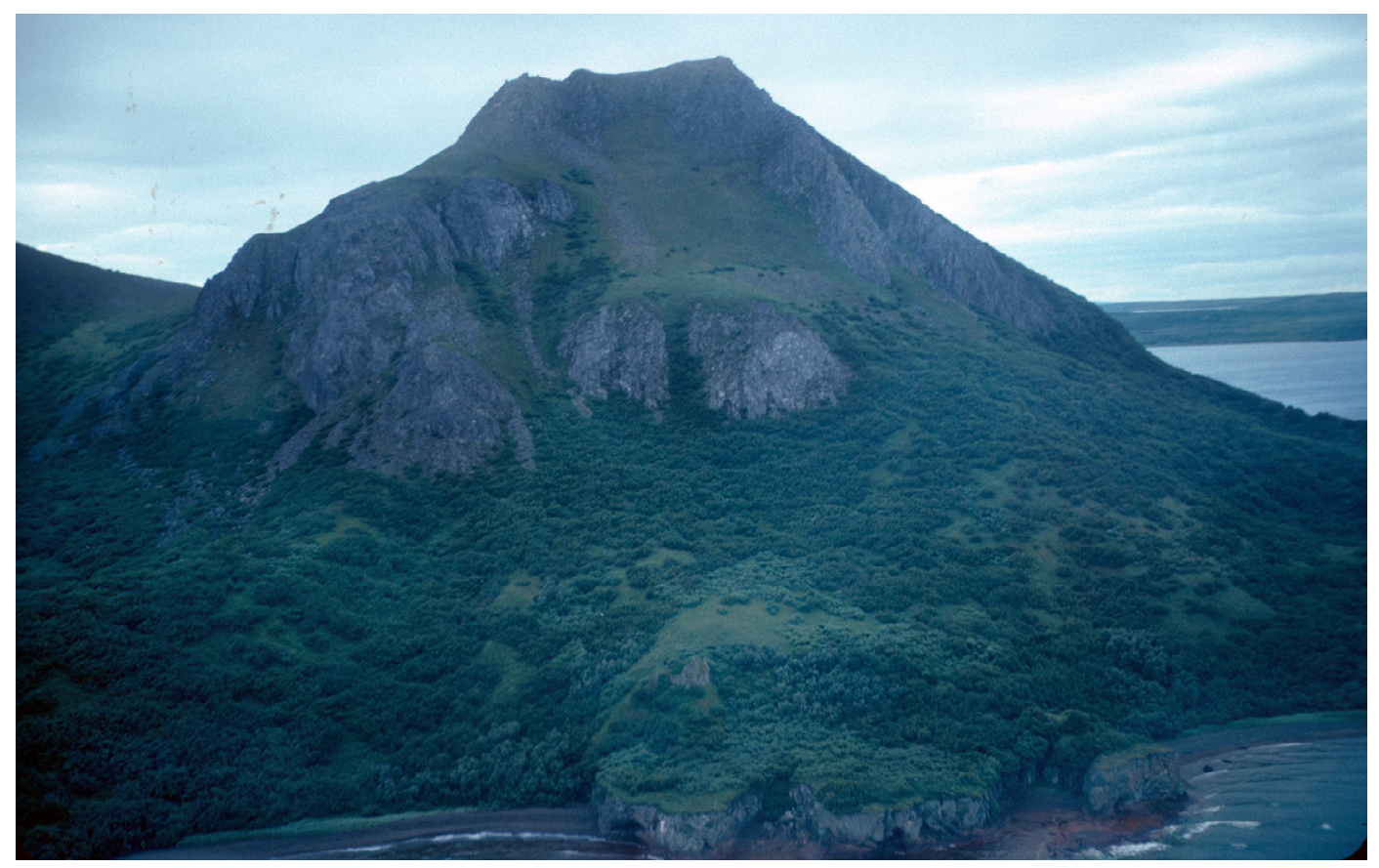

Figure 13. Northeast face of Dome 600 at The Gas Rocks (fig. 3B). Lava flows, probably coeruptive with dome, crop out along foreground cliff at lakeshore. Steep jointing flares gently outward toward top of dome.

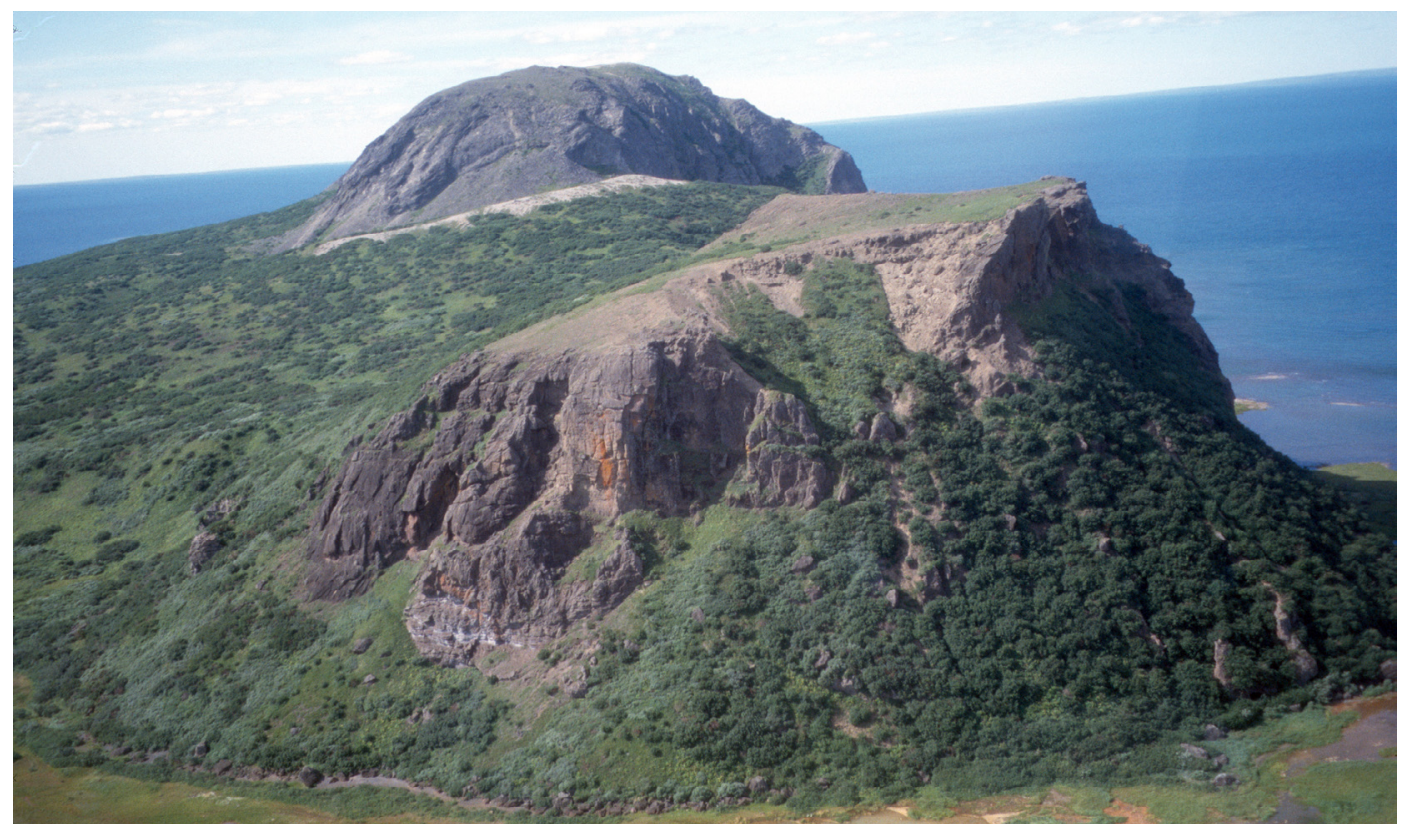

Figure 14. Mafic ejecta Cone 431 at The Gas Rocks (fig. 3B), with dacite Dome 700 in background, viewed northwestward. Induration of fragmental cone deposits reflects weak palagonitization following warm wet emplacement, and gentle westerly dip of strata indicates that its vent was over present-day lake. Sheeted aspect of left (west) side of dome, which elsewhere is steeply jointed, suggests multipulse exogenous extrusion. Pale-gray curvilinear ridge of well-rounded cobble-pebble gravel (also visible in fig. 10) at foot of dome is neither till nor an ejecta ring; its $15^{\circ}$ inclination is hard to reconcile with its having been a beach deposit, unless it were tilted by postglacial isostatic rebound. Stones consist mostly of porphyritic andesite-dacite that differs from local dome rock; chunks of indurated ash from adjacent mafic Cone 431 are present, but granitoids and sandstone are rare or absent, suggesting subglacial fluvial transport of clasts directly from the Peulik-Ugashik edifice. 
Table 2. Geochronologic analyses of samples of volcanic rocks from Blue Mountain and The Gas Rocks.

[Ar-isotope intensities (in volts; $1 \mathrm{~V}$ is equivalent to $3.06 \times 10^{-14} \mathrm{~mol}$ ) corrected for blanks, backgrounds, and radioactive decay. Reactor-produced corrections: ${ }^{40} \mathrm{Ar} /{ }^{39} \mathrm{Ar} \mathrm{K}_{\mathrm{K}}=0.000 \pm 0.004$, $\left.{ }^{39} \mathrm{Ar}^{\beta^{77}} \mathrm{Ar}_{\mathrm{Ca}}=0.000706 \pm 0.000051,{ }^{36} \mathrm{Ar}^{\beta 7} \mathrm{Ar}_{\mathrm{Ca}}=0.000281 \pm 0.000009\right]$

\begin{tabular}{|c|c|c|c|c|c|c|c|c|c|c|c|c|c|c|c|c|}
\hline $\begin{array}{c}\text { Temperature } \\
\left({ }^{\circ} \mathrm{C}\right)\end{array}$ & Age (ka) & $\%$ rad & $\begin{array}{l}\mathrm{K} / \mathrm{Ca} \\
\text { ratio }\end{array}$ & $\begin{array}{l}\mathrm{K} / \mathrm{Cl} \\
\text { ratio }\end{array}$ & $\begin{array}{c}{ }^{40} \mathrm{Ar}^{*} \\
\left(\times 10^{-14} \mathrm{~mol}\right)\end{array}$ & $\Sigma^{39} \mathrm{Ar}$ & ${ }^{40} \mathrm{Ar}$ & $\pm^{40} \mathrm{Ar}$ & ${ }^{39} \mathrm{Ar}$ & $\pm^{39} \mathrm{Ar}$ & ${ }^{38} \mathrm{Ar}$ & $\pm^{38} \mathrm{Ar}$ & ${ }^{37} \mathrm{Ar}$ & $\pm^{37} \mathrm{Ar}$ & ${ }^{36} \mathrm{Ar}$ & $\pm{ }^{36} \mathrm{Ar}$ \\
\hline \multicolumn{17}{|c|}{ Sample U-1, dacite } \\
\hline 550 & $23.11 \pm 7.70$ & 2.1 & 1.854 & $-39,050$ & 0.07 & 0.05 & 1.058962 & 0.002124 & 0.629478 & 0.001273 & 0.008630 & 0.000075 & 0.178133 & 0.001305 & 0.003559 & 0.000021 \\
\hline 590 & $20.31 \pm 4.84$ & 3.0 & 1.973 & $-10,860$ & 0.09 & 0.13 & 0.937376 & 0.001881 & 0.908789 & 0.001837 & 0.011827 & 0.000070 & 0.241693 & 0.001450 & 0.003146 & 0.000020 \\
\hline 630 & $26.67 \pm 3.10$ & 6.1 & 1.924 & $-11,770$ & 0.17 & 0.25 & 0.906046 & 0.001900 & 1.367927 & 0.002764 & 0.017517 & 0.000070 & 0.373045 & 0.002123 & 0.002985 & 0.000019 \\
\hline 670 & $24.40 \pm 2.57$ & 6.9 & 1.766 & $-25,220$ & 0.21 & 0.41 & 0.999475 & 0.002087 & 1.867238 & 0.003773 & 0.024129 & 0.000096 & 0.554720 & 0.002189 & 0.003306 & 0.000021 \\
\hline 700 & $20.34 \pm 3.97$ & 5.8 & 1.481 & 73,710 & 0.14 & 0.54 & 0.809164 & 0.001707 & 1.534063 & 0.003100 & 0.020174 & 0.000083 & 0.543190 & 0.001940 & 0.002732 & 0.000030 \\
\hline 730 & $26.92 \pm 5.17$ & 5.4 & 1.120 & 16,030 & 0.15 & 0.64 & 0.915855 & 0.001920 & 1.211802 & 0.002449 & 0.016361 & 0.000082 & 0.567341 & 0.002743 & 0.003092 & 0.000030 \\
\hline 760 & $26.67 \pm 6.33$ & 3.1 & 0.804 & 6,835 & 0.10 & 0.71 & 1.080185 & 0.002248 & 0.828743 & 0.001676 & 0.011778 & 0.000077 & 0.540302 & 0.001968 & 0.003695 & 0.000023 \\
\hline 800 & $32.41 \pm 7.52$ & 3.2 & 0.602 & 4,587 & 0.10 & 0.77 & 1.037506 & 0.002163 & 0.671839 & 0.001359 & 0.009857 & 0.000065 & 0.585621 & 0.002570 & 0.003565 & 0.000023 \\
\hline 850 & $31.45 \pm 6.64$ & 3.8 & 0.552 & 2,831 & 0.10 & 0.83 & 0.826967 & 0.001705 & 0.662180 & 0.001339 & 0.009977 & 0.000068 & 0.628814 & 0.002494 & 0.002869 & 0.000020 \\
\hline 900 & $34.56 \pm 5.40$ & 4.5 & 0.678 & 1,950 & 0.12 & 0.89 & 0.894151 & 0.001839 & 0.774427 & 0.001566 & 0.012147 & 0.000078 & 0.598708 & 0.002514 & 0.003058 & 0.000018 \\
\hline 950 & $31.50 \pm 7.92$ & 2.4 & 0.577 & 1,459 & 0.10 & 0.95 & 1.370720 & 0.002791 & 0.706221 & 0.001428 & 0.011956 & 0.000091 & 0.641303 & 0.002480 & 0.004705 & 0.000023 \\
\hline 1,025 & $91.56 \pm 14.29$ & 3.4 & 0.188 & 495 & 0.20 & 0.99 & 1.870596 & 0.003791 & 0.466725 & 0.000945 & 0.011174 & 0.000060 & 1.300003 & 0.003128 & 0.006478 & 0.000026 \\
\hline 1,100 & $156.67 \pm 44.32$ & 3.7 & 0.074 & 336 & 0.07 & 1.00 & 0.604128 & 0.001261 & 0.094632 & 0.000194 & 0.002797 & 0.000034 & 0.668915 & 0.002978 & 0.002157 & 0.000020 \\
\hline \multicolumn{17}{|c|}{ Sample U-2, dacite } \\
\hline 550 & $-391.04 \pm 11.02$ & -59.1 & 1.769 & $-5,935$ & -0.88 & 0.04 & 0.485854 & 0.001148 & 0.547885 & 0.001103 & 0.007093 & 0.000063 & 0.162454 & 0.001201 & 0.002662 & 0.000026 \\
\hline 575 & $10.23 \pm 6.81$ & 1.9 & 1.854 & $-6,398$ & 0.02 & 0.09 & 0.410869 & 0.000903 & 0.578270 & 0.001164 & 0.007255 & 0.000084 & 0.163590 & 0.001080 & 0.001410 & 0.000017 \\
\hline 600 & $25.55 \pm 4.54$ & 6.2 & 1.863 & $-9,717$ & 0.10 & 0.16 & 0.501862 & 0.001082 & 0.908273 & 0.001827 & 0.011501 & 0.000068 & 0.255726 & 0.000824 & 0.001665 & 0.000018 \\
\hline 630 & $25.93 \pm 3.02$ & 7.9 & 1.794 & $-8,828$ & 0.13 & 0.26 & 0.557596 & 0.001192 & 1.260670 & 0.002536 & 0.015820 & 0.000096 & 0.368740 & 0.001554 & 0.001842 & 0.000016 \\
\hline 660 & $23.89 \pm 2.72$ & 8.7 & 1.605 & $-8,289$ & 0.15 & 0.38 & 0.572958 & 0.001223 & 1.556697 & 0.003131 & 0.019416 & 0.000113 & 0.508888 & 0.001627 & 0.001913 & 0.000018 \\
\hline 690 & $18.99 \pm 2.64$ & 7.5 & 1.341 & $-28,730$ & 0.12 & 0.50 & 0.543596 & 0.001162 & 1.599063 & 0.003216 & 0.020514 & 0.000158 & 0.625506 & 0.002521 & 0.001878 & 0.000018 \\
\hline 720 & $23.22 \pm 2.95$ & 8.3 & 1.041 & 166,600 & 0.14 & 0.62 & 0.557911 & 0.001190 & 1.485542 & 0.002988 & 0.019350 & 0.000111 & 0.748557 & 0.001832 & 0.001942 & 0.000019 \\
\hline 750 & $22.03 \pm 3.56$ & 5.6 & 0.758 & 8,278 & 0.10 & 0.71 & 0.601638 & 0.001277 & 1.141349 & 0.002296 & 0.015545 & 0.000131 & 0.789730 & 0.001809 & 0.002144 & 0.000017 \\
\hline 800 & $28.65 \pm 4.68$ & 4.8 & 0.496 & 3,717 & 0.12 & 0.78 & 0.806770 & 0.001686 & 1.017951 & 0.002048 & 0.014685 & 0.000128 & 1.075222 & 0.002294 & 0.002900 & 0.000019 \\
\hline 875 & $8.54 \pm 4.63$ & 1.4 & 0.367 & 2,053 & 0.04 & 0.86 & 0.811116 & 0.001695 & 1.005626 & 0.002023 & 0.015482 & 0.000122 & 1.436282 & 0.003049 & 0.003110 & 0.000019 \\
\hline 950 & $21.44 \pm 5.01$ & 3.6 & 0.496 & 1,529 & 0.09 & 0.94 & 0.800746 & 0.001674 & 1.009629 & 0.002031 & 0.016238 & 0.000099 & 1.067986 & 0.002472 & 0.002912 & 0.000021 \\
\hline 1,050 & $54.59 \pm 10.59$ & 2.9 & 0.228 & 565 & 0.14 & 0.99 & 1.610054 & 0.003291 & 0.648012 & 0.001304 & 0.014213 & 0.000101 & 1.487950 & 0.003157 & 0.005706 & 0.000024 \\
\hline 1,150 & $-200.43 \pm 49.99$ & -4.9 & 0.052 & 400 & -0.09 & 1.00 & 0.587802 & 0.001250 & 0.108359 & 0.000220 & 0.002956 & 0.000054 & 1.087459 & 0.004056 & 0.002393 & 0.000023 \\
\hline
\end{tabular}


Table 2. Geochronologic analyses of samples of volcanic rocks from Blue Mountain and The Gas Rocks. - Continued

[Ar-isotope intensities (in volts; $1 \mathrm{~V}$ is equivalent to $3.06 \times 10^{-14} \mathrm{~mol}$ ) corrected for blanks, backgrounds, and radioactive decay. Reactor-produced corrections: ${ }^{40} \mathrm{Ar} /{ }^{39} \mathrm{Ar} \mathrm{K}_{\mathrm{K}}=0.000 \pm 0.004$, $\left.{ }^{39} \mathrm{Ar}^{\beta 7} \mathrm{Ar}_{\mathrm{Ca}}=0.000706 \pm 0.000051,{ }^{36} \mathrm{Ar}{ }^{\beta 7} \mathrm{Ar}_{\mathrm{Ca}}=0.000281 \pm 0.000009\right]$

\begin{tabular}{|c|c|c|c|c|c|c|c|c|c|c|c|c|c|c|c|c|}
\hline $\begin{array}{c}\text { Temperature } \\
\left({ }^{\circ} \mathrm{C}\right)\end{array}$ & Age (ka) & $\%$ rad & $\begin{array}{l}\mathrm{K} / \mathrm{Ca} \\
\text { ratio }\end{array}$ & $\begin{array}{l}\mathrm{K} / \mathrm{Cl} \\
\text { ratio }\end{array}$ & $\begin{array}{c}{ }^{40} \mathrm{Ar}^{*} \\
\left(\times 10^{-14} \mathrm{~mol}\right)\end{array}$ & $\sum^{39} \mathrm{Ar}$ & ${ }^{40} \mathrm{Ar}$ & $\pm^{40} \mathrm{Ar}$ & ${ }^{39} \mathrm{Ar}$ & $\pm^{39} \mathrm{Ar}$ & ${ }^{38} \mathrm{Ar}$ & $\pm^{38} \mathrm{Ar}$ & ${ }^{37} \mathrm{Ar}$ & $\pm^{37} \mathrm{Ar}$ & ${ }^{36} \mathrm{Ar}$ & $\pm^{36} \mathrm{Ar}$ \\
\hline \multicolumn{17}{|c|}{ Sample U-19, dacite } \\
\hline 550 & $717.10 \pm 58.08$ & 45.3 & 0.714 & $-581,700$ & 0.14 & 0.02 & 0.099810 & 0.000250 & 0.040910 & 0.000092 & 0.000557 & 0.000022 & 0.030030 & 0.000806 & 0.000193 & 0.000012 \\
\hline 600 & $636.38 \pm 17.77$ & 44.9 & 0.499 & 7,666 & 0.49 & 0.11 & 0.359125 & 0.000762 & 0.164139 & 0.000334 & 0.002317 & 0.000031 & 0.172384 & 0.001760 & 0.000719 & 0.000015 \\
\hline 650 & $620.98 \pm 13.30$ & 48.4 & 0.381 & 3,528 & 0.97 & 0.29 & 0.658391 & 0.001359 & 0.332698 & 0.000674 & 0.004879 & 0.000041 & 0.457880 & 0.002023 & 0.001279 & 0.000022 \\
\hline 700 & $631.02 \pm 10.64$ & 44.5 & 0.253 & 2,727 & 1.13 & 0.49 & 0.828666 & 0.001700 & 0.378995 & 0.000767 & 0.005745 & 0.000053 & 0.783635 & 0.002928 & 0.001777 & 0.000019 \\
\hline 750 & $637.06 \pm 14.72$ & 34.3 & 0.145 & 2,211 & 0.80 & 0.64 & 0.764687 & 0.001572 & 0.267157 & 0.000542 & 0.004270 & 0.000052 & 0.967504 & 0.002702 & 0.001973 & 0.000019 \\
\hline 800 & $531.00 \pm 18.62$ & 22.9 & 0.102 & 2,334 & 0.50 & 0.74 & 0.717610 & 0.001478 & 0.200916 & 0.000408 & 0.003309 & 0.000038 & 1.033376 & 0.002411 & 0.002164 & 0.000018 \\
\hline 875 & $447.77 \pm 25.89$ & 14.7 & 0.090 & 1,458 & 0.38 & 0.84 & 0.841130 & 0.001733 & 0.179221 & 0.000364 & 0.003293 & 0.000039 & 1.045587 & 0.002790 & 0.002723 & 0.000022 \\
\hline 950 & $415.87 \pm 36.21$ & 9.1 & 0.087 & 624 & 0.25 & 0.91 & 0.896292 & 0.001843 & 0.127673 & 0.000260 & 0.003039 & 0.000042 & 0.762657 & 0.003349 & 0.002971 & 0.000022 \\
\hline 1,025 & $572.06 \pm 41.27$ & 9.6 & 0.068 & 315 & 0.32 & 0.97 & 1.104360 & 0.002258 & 0.120162 & 0.000245 & 0.003818 & 0.000048 & 0.928219 & 0.003124 & 0.003641 & 0.000022 \\
\hline 1,100 & $203.20 \pm 100.17$ & 1.5 & 0.028 & 434 & 0.05 & 1.00 & 1.077863 & 0.002205 & 0.051762 & 0.000125 & 0.001861 & 0.000034 & 0.956781 & 0.003814 & 0.003862 & 0.000023 \\
\hline
\end{tabular}

SAMPLES:

U-1. Dacite, $0.1472 \mathrm{~g}$, irradiation packet IRR233-SE, experiment 06Z0170. $J$ neutron-flux parameter, 0.0003675 \pm 0.000000499 ; total-gas age, 29.9 \pm 1.4 ka; weighted-mean plateau age, 25.7 \pm 1.4 ; isochron age, $21.6 \pm 2.9 \mathrm{ka}$; mean square of weighted deviates, $0.80 ;{ }^{40} \mathrm{Ar}^{36} \mathrm{Ar}_{\mathrm{i}}=297.7 \pm 1.5$.

U-2. Dacite, $0.144 \mathrm{~g}$, irradiation packet IRR232-RY, experiment 06Z0038. $J$ neutron-flux parameter, $0.0004132 \pm 0.000000662$; total-gas age, $3.7 \pm 1.2 \mathrm{ka}$; weighted-mean plateau age, $23.3 \pm 1.2(69.7$ percent of gas released); isochron age, $20.5 \pm 5.4$; mean square of weighted deviates, $0.29 ;{ }^{40} \mathrm{Ar} /{ }^{36} \mathrm{Ar}_{\mathrm{i}}=299.1 \pm 4.7$.

U-19. Dacite, $0.1502 \mathrm{~g}$, irradiation packet IRR233-SF, experiment 06Z0171. $J$ neutron-flux parameter, $0.0003592 \pm 0.000000488$; total-gas age, $573.8 \pm 6.7 \mathrm{ka}$; weighted-mean plateau age, $631.6 \pm 6.8 \mathrm{ka}$; isochron age, $610 \pm 29 \mathrm{ka}$; mean square of weighted deviates, $0.7 ;{ }^{40} \mathrm{Ar} /{ }^{36} \mathrm{Ari}=301.2 \pm 16.7$. 
Gas Rocks domes (fig. 3), (2) numerous tiny bubble trains in the same offshore area, (3) a brine-rich bubbling hot spring or seep at the northeast base of The Gas Rocks, and (4) a few cold bubbling seeps and puddles and extensive diffuse $\mathrm{CO}_{2}$ discharge along the low ridge 2 to $3 \mathrm{~km}$ south of The Gas Rocks that included the site of the 1977 Ukinrek eruption. In several patches along the ridge 1 to $2 \mathrm{~km}$ east of the 1977 craters, soil $\mathrm{CO}_{2}$ is sufficiently concentrated to kill vegetation that had grown back atop the 1977 basaltic fallout deposits (Evans and others, 2007).

Sporadic observations by many geologists suggest that gas discharge and thermal-spring activity were enhanced around the time of the 1977 Ukinrek eruption but have diminished subsequently. The hot spring at the northeast end of the peninsula cooled from $53^{\circ} \mathrm{C}$ in 1977 , through $39^{\circ} \mathrm{C}$ in 1981 , to $16^{\circ} \mathrm{C}$ by 1995 (Symonds and others, 1997). Its salinity dropped greatly, its discharge decreased to less than $1 \mathrm{~L} / \mathrm{min}$ by 1995 , and the spring was not observed at all in 2003 or 2004. Lakes inside Ukinrek Maars, as hot as $81^{\circ} \mathrm{C}$ in 1977 , cooled to $16^{\circ} \mathrm{C}$ in 1981 and froze over by 1996. Although gas flux apparently

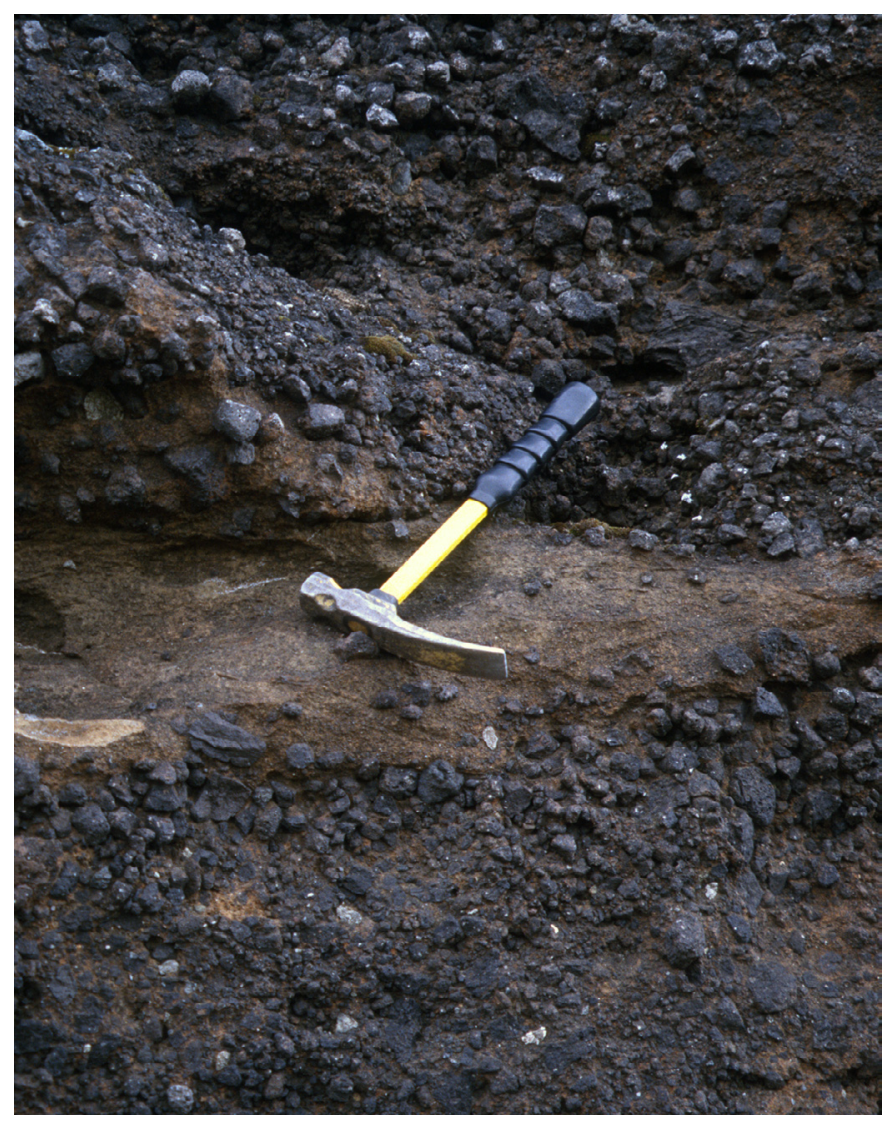

Figure 15. Basaltic ejecta near top of mafic Cone 431 at The Gas Rocks (fig. 3B). Poorly to moderately vesicular lapilli dominate poorly sorted fall units, typically meters thick, which exhibit crude internal variations in grain size and are separated by irregular layers and lenses of coarse palagonitized ash. Hammer is $32 \mathrm{~cm}$ long. diminished, the dry gas (subtracting water and atmospheric contaminants) remained 90 to 99 volume percent $\mathrm{CO}_{2}$ from 1977 through 2004. Likewise, isotopic compositions of the dry gas changed little. The He-isotope ratio has been 6 to 7 $\mathrm{Ra}$, and the $\delta^{13} \mathrm{C}$ value has remained -7.1 to -6.1 (Motyka and others, 1993; Symonds and others, 1997; Evans and others, 2007), each well within the expected range for a mantle-dominated gas source. Compositional constancy at all three sites (offshore, the onshore bubbling spring, and bubbling seeps on the ridge) implies a common source and little change (during the decades of observation) in either the mantle source or the amount of crustal contamination.

Despite proximity, the gas flux is clearly unrelated to the 25-ka Gas Rocks dacites. The inferred relation between enhanced gas flux and the 1977 Ukinrek eruption, as well as the presence of four other rear-arc basalts nearby, suggests that mantle-derived fluids have a relatively easy path to the surface in this area. Evans and others (2007) estimated a diffuse $\mathrm{CO}_{2}$ discharge in June 2004 of at least 44 tonnes per day $(\mathrm{t} / \mathrm{d})$ along the ridge and only $0.5 \mathrm{t} / \mathrm{d}$ from the conspicuous upwellings offshore from The Gas Rocks. They plausibly suggested that the alkalic Ukinrek magma had attained saturation in $\mathrm{CO}_{2}$ while intruding upward through the crust for years before 1977, releasing gas to the nearby surface for decades before and after the eruption. We note that the three main sites of gas emission-The Gas Rocks, Ukinrek Maars, and the vegetation-kill areas along the ridge east of the maars - are not well aligned along the presumed trace of the Bruin Bay or any other known fault (fig. 2).

\section{Compositions of the Volcanic Rocks}

Chemical data for 38 rock samples, representing all the units discussed, are plotted in figure 8 and listed in table 1 . Sample locations are shown in figure 3, except for the small Gertrude Creek, Ukinrek, and Lone basaltic outcrops shown in figure 2. All analyses were by X-ray fluorescence (XRF), as explained in table 1.

All the eruptive suites are medium-K, calcic, low-Ti, low-Nb, aluminous arc rocks. The dome clusters at Blue Mountain and The Gas Rocks yield compositional arrays ranging from silicic andesite to dacite, and their chilled magmatic enclaves consist of basaltic andesite. The fairly continuous arrays from basalt through dacite suggest repeated intracrustal processing of broadly similar parental magmas by interaction (fractionation, assimilation, and mixing) within a common crustal column beneath this limited rear-arc area. The linear arrays show that the dacites are not simply crustal partial melts, and their moderate $\mathrm{Sr}$ and Y contents (400-560 and 13-22 ppm, respectively, table 1) and modest $\mathrm{Sr} / \mathrm{Y}$ ratios (20-35) indicate that they are not partial melts extracted from an eclogitic residue. The dacites have low contents of $\mathrm{MgO}$ (1.1-2.7 weight percent), $\mathrm{Ni}$ (7-28 ppm), and $\mathrm{Cr}$ (7-50 ppm) and are only moderately enriched in $\mathrm{La}(18-27 \mathrm{ppm})$ and $\mathrm{Ce}$ 


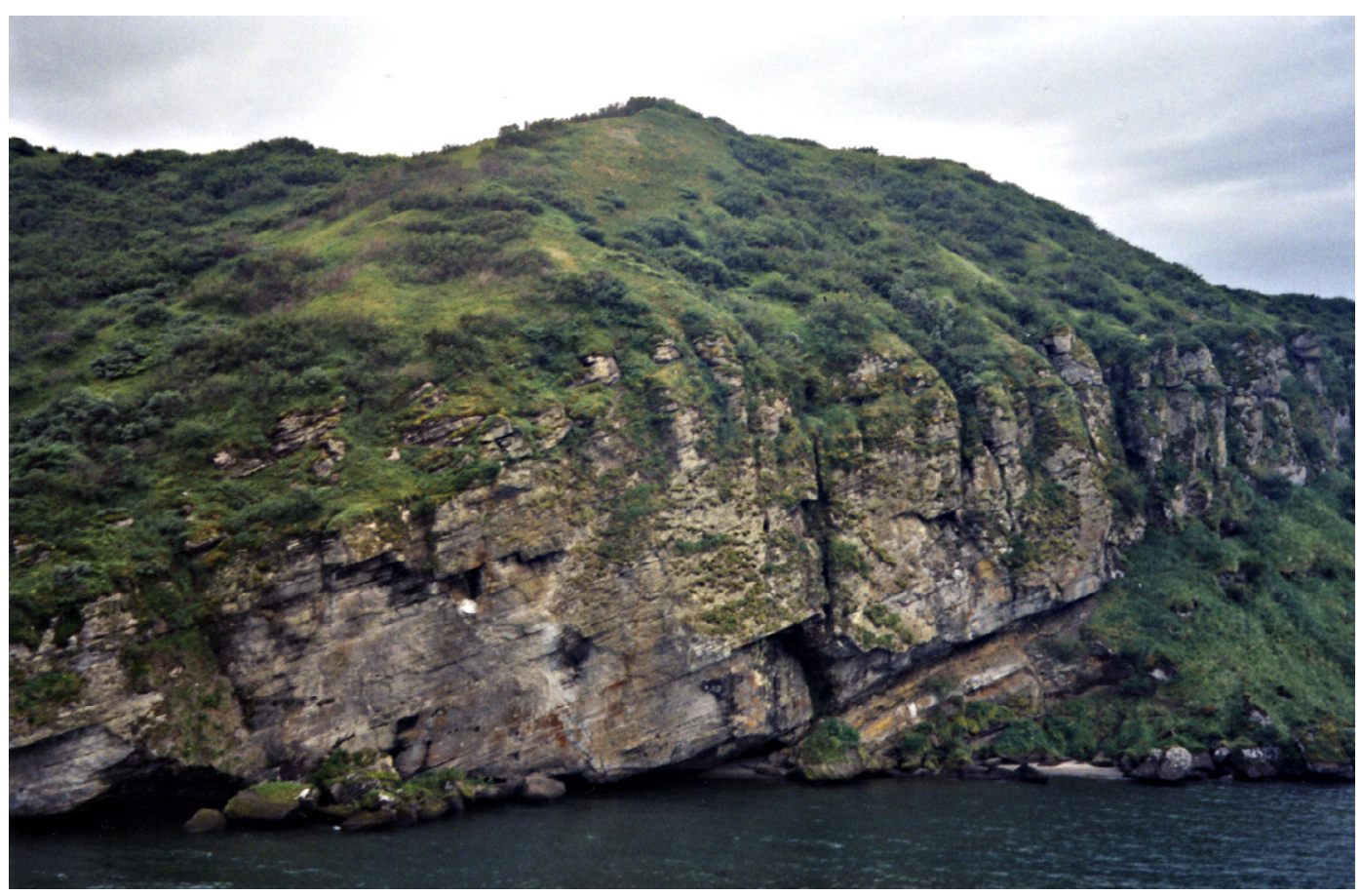

Figure 16. Well-stratified basaltic phreatomagmatic ejecta exposed along cliff at south shore of Becharof Lake, $4 \mathrm{~km}$ west of The Gas Rocks (fig. 3B). Exposure is 25 to $30 \mathrm{~m}$ high, overlain by surficial deposits that culminate in Hill 254 on skyline.

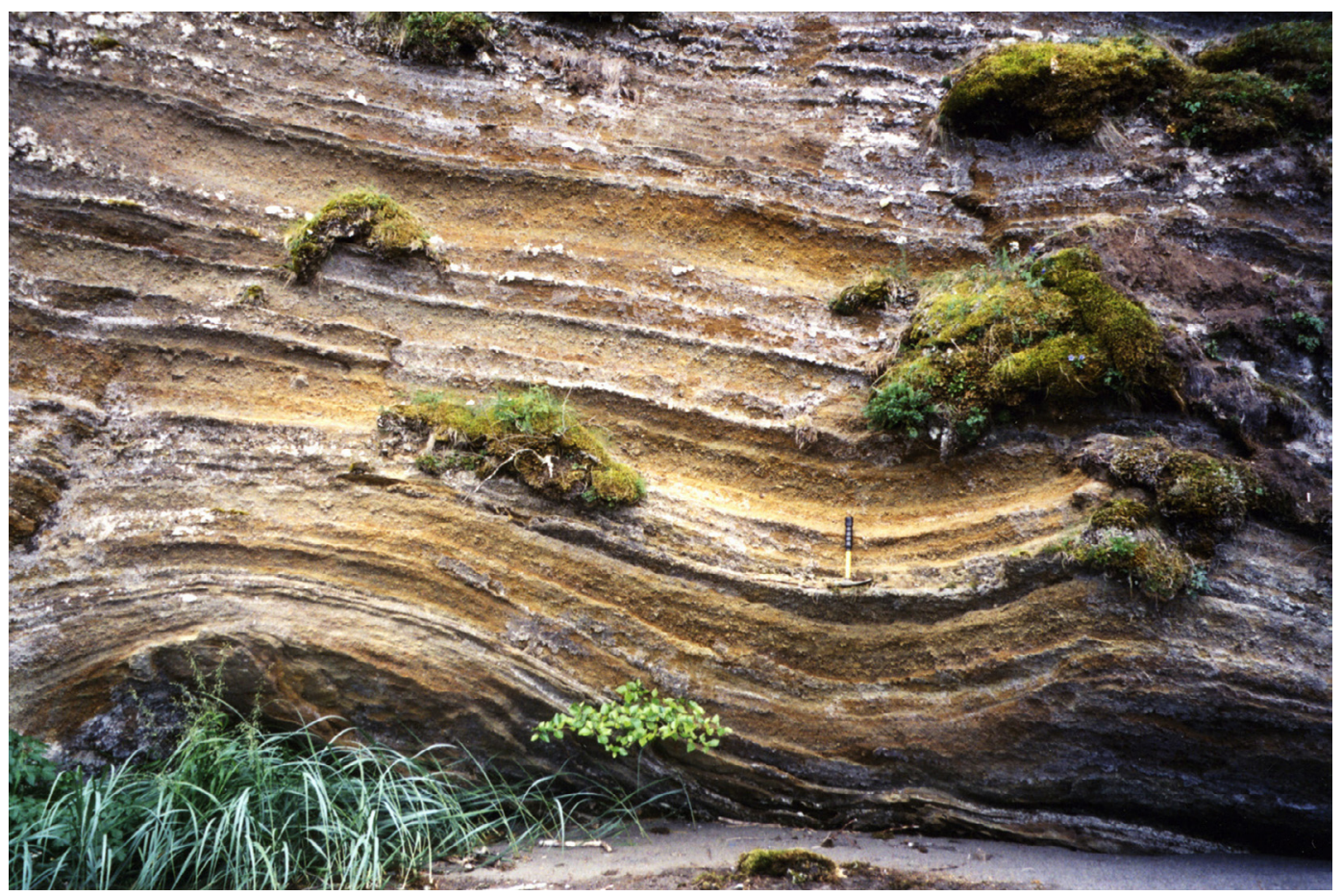

Figure 17. Basaltic phreatomagmatic deposit of Cone 254 at beach level on south shore of Becharof Lake (fig. 3B), showing undulatory bedding below and planar bedding above. Lapilli-fall layers alternate with thinner ash-rich surge deposits, 1 to $5 \mathrm{~cm}$ thick, that weather out in relief. Hammer is $32 \mathrm{~cm}$ long. 
(31-41 ppm). The Gas Rocks and Blue Mountain dacites are quite similar chemically and mineralogically, except that The Gas Rocks dacites are somewhat more sodic and marginally poorer in $\mathrm{Ca}$ and $\mathrm{Sr}$ (at any particular $\mathrm{SiO}_{2}$ content).

Dacites (and most of the mafic enclaves) of both dome clusters are enriched in $\mathrm{K}$ (and in $\mathrm{Ba}$ and $\mathrm{Rb}$ ) relative to equivalents in the Peulik-Ugashik eruptive suite (52-72 weight percent $\mathrm{SiO}_{2}$, fig. 8; table 1) on the nearby arc front (Miller, 2004), possibly reflecting somewhat greater intraplate contributions to the evolving rear-arc magmas. The Gas Rocks suite is more sodic, and the Blue Mountain suite less sodic, than the Peulik-Ugashik array. The Blue Mountain suite is richer in $\mathrm{Sr}$ and poorer in $\mathrm{Zr}$ than either of the other suites. An unusually ragged $\mathrm{Zr}-\mathrm{SiO}_{2}$ array for the Blue Mountain samples (not shown) may reflect zircon fractionation, inhomogeneous distribution of tiny zircons in the crystal-rich dome lavas, or a nugget effect in the samples crushed.

The six sets of mafic rocks are fundamentally similar to each other - all subalkalic, aluminous, and with fairly low Ti, $\mathrm{Zr}$, and $\mathrm{Nb}$ contents (table 1). The basalt of Ukinrek Maars was called alkalic by Kienle and others (1980), but this designation holds only by the Hawaiian criteria of Macdonald and Katsura (1964). By the criteria of Irvine and Baragar (1971) this basalt is marginally subalkaline, and by those of Le Bas and others (1986) unequivocally subalkaline (fig. 8). At 48 weight percent $\mathrm{SiO}_{2}$ and 9.5 weight percent $\mathrm{MgO}$, the basalt of Ukinrek Maars is more primitive than nearly all other rocks in the study area (figs. 1, 2), except for a basaltic bomb from Cone 254 that is comparable in $\mathrm{MgO}$ content and much richer in $\mathrm{Ni}$ and $\mathrm{Cr}$ than the Ukinrek ejecta (table 1). Rich in $\mathrm{Ca}$ and $\mathrm{Mg}$, the basalt of Cone 254 ( 51.5 weight percent $\mathrm{SiO}_{2}$ ) is the most strongly subalkaline mafic rock in the study area, with lower $\mathrm{Na}, \mathrm{K}, \mathrm{Rb}$, $\mathrm{Sr}, \mathrm{Ba}, \mathrm{Zr}$, and Fe contents than any other. A systematic analysis of the compositional differences among rear-arc mafic volcanic rocks on the Alaska Peninsula and those on the nearby volcanic front was presented by Hildreth and others (2004).

\section{Geochronology}

The methods for determining ${ }^{40} \mathrm{Ar} /{ }^{39} \mathrm{Ar}$ ages at the USGS laboratory in Menlo Park, Calif., are detailed in the appendix. All three samples dated yielded plateau ages, here defined as at least 50 percent of ${ }^{39} \mathrm{Ar}$ released within $\pm 2 \sigma$ error on contiguous heating steps; these results generally have correspondingly good isochron fits. Because all the isochron fits yielded ${ }^{40} \mathrm{Ar} /{ }^{36} \mathrm{Ar}$ intercepts within $2 \sigma$ of atmosphere, we interpret the plateau ages as most reliable. Discordant steps at low and high temperatures are interpreted as a result of modest excess ${ }^{40} \mathrm{Ar}$ (sample U-1, dacite), ${ }^{40} \mathrm{Ar}$ loss (sample U-2, dacite) or

${ }^{39} \mathrm{Ar}$ recoil (sample U-19, dacite, table 2). Calvert and others

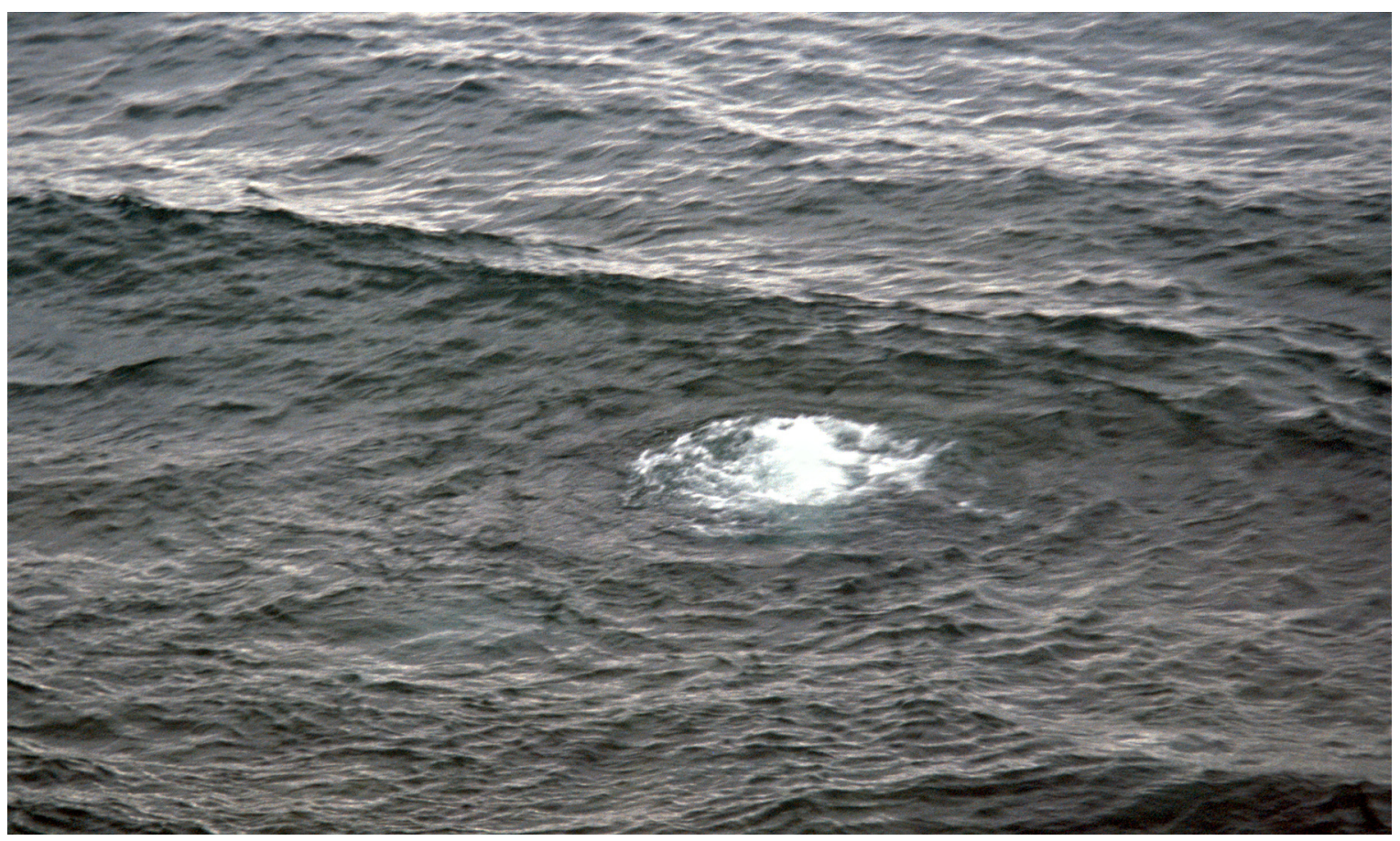

Figure 18. Upwelling plume of cold lakewater charged with bubbles of $\mathrm{CO}_{2}$ forms a persistent churning boil, here $\sim 1 \mathrm{~m}$ in diameter. Several such upwellings have long been noted in Becharof Lake, about 10 to $80 \mathrm{~m}$ off northeast shore of The Gas Rocks. 
(2005) discussed the mechanisms that yield discordant age spectra, including recoil, excess ${ }^{40} \mathrm{Ar}$, and Ar loss.

Analytical results are summarized in figure 9, and stepheating analytical data are listed in table 2 . The two ages for The Gas Rocks (samples U-1 from North Point Dome and U-2 from Dome 600) are 25.7 \pm 1.4 and 23.3 $\pm 1.2 \mathrm{ka}$, respectively. Because their $\pm 1 \sigma$ error envelopes overlap (barely), there need be little real age difference between the contiguous domes. The dated Blue Mountain sample (U-19) is from a lava flow extruded from the central and highest dome of the cluster; its age of $631.6 \pm 6.8 \mathrm{ka}$ is probably (but not certainly) close to those of all 13 domes in the cluster.

The K-Ar ages determined by Wilson and Shew (1992) differ significantly from our results. Their Gas Rocks sample 79AMm 34 yielded discordant mineral (biotite, plagioclase, and hornblende) ages 5 to 25 times older than ours. We interpret all these ages as far too old and suspect that each split contained substantial excess ${ }^{40} \mathrm{Ar}$. Their Blue Mountain mineral data also vary widely, although individual samples appear to have been reproducible. Ages on plagioclase from their dacite samples 79ADt 135, 79AYb 90, and 81ASh 2 range from 1.09 to 1.66 $\mathrm{Ma}$, more than is likely for such a compact dome cluster. Their whole-rock K-Ar age (593 $\pm 72 \mathrm{ka}$ ) for sample 81AWs 275 of the Lone basalt, however, is similar to the ${ }^{40} \mathrm{Ar} /{ }^{\beta 9} \mathrm{Ar}$ age for sample U-19 dacite reported here, suggesting an approximate contemporaneity between the basaltic eruption and the crustal magmatism that produced the Blue Mountain dacite cluster 10 $\mathrm{km}$ away. We interpret their age for the basalt to be reliable and suspect that the discordant mineral separates from Blue Mountain dacites were contaminated with excess ${ }^{40} \mathrm{Ar}$.

\section{Discussion}

Although Quaternary basalts are rare on the Alaska Peninsula, at least five were erupted within the study area (figs. 1,2). Rear-arc eruptive centers of any composition are uncommon along the entire, generally single file Alaska-Aleutian volcanic chain, but in this limited area alone are two reararc dacite dome clusters, as well as the several rear-arc basaltic vents, all middle Pleistocene or younger. The dacites can plausibly be related to the basaltic input, whether by crystal-melt fractionation, crustal melting, or complex hybridization. The main tectonomagmatic problem is to identify what structures or processes might favor rear-arc volcanism here when it is so uncommon elsewhere along the arc.

The Bruin Bay Fault zone is an obvious candidate to have exerted some influence over passage of Quaternary magmas through the upper crust, even though this southwesterly part of the fault zone appears not to have been active since the Oligocene or earlier. From its undulatory trace in the Katmai region to the northeast (fig. 1), the fault is presumably a steeply dipping, but nonvertical, shear zone of uncertain breadth. If a leaky shear zone were implicated here, however, why do no other Quaternary volcanic rocks occur along or near the fault zone in the $300-\mathrm{km}$ reach (fig. 1) between Gertrude Creek and Mount Iliamna?
A plausible explanation may lie in the local intersection of the Bruin Bay Fault zone with a cryptic transverse structural zone (fig. 1), as proposed by Fisher and others (1981). Their northwest-trending crossarc zone (as modified slightly in fig. 1) includes all the rear-arc volcanoes discussed in this study, as well as the $35-\mathrm{km}$ seaward offset of the Chiginagak segment from the Peulik-Katmai segment of the arc front. As summarized by Fisher and others, the transverse structural zone also includes a change in the sign of the Bouguer gravity anomaly along the Alaska Peninsula, an abrupt decrease in amplitude of the offshore magnetic anomaly that follows Shelikof Strait, and deflection of shelf-edge structures off the southwest end of Kodiak Island. Moreover, the zone coincides with abrupt drops in topographic and structural relief toward the southwest. The Kodiak Island accretionary terrane becomes submerged, and the range-crest elevations of Late Jurassic (Naknek Formation) strata that form the drainage divide along the peninsula drop from more than 1,500 to $\sim 500 \mathrm{~m}$ adjacent to Becharof and Ugashik Lakes, one of the lowest reaches along the Alaska Peninsula. North of the Bruin Bay Fault, Jurassic batholithic rocks are exposed at the surface virtually continuously for hundreds of kilometers from Becharof Lake to the northeast, but within the transverse structural zone the batholith is abruptly buried by $>3 \mathrm{~km}$ of Tertiary sedimentary rocks (fig. 2; MacNeil and others, 1961). Though not known to coincide with any major crossarc faults, the zone does coincide with a sharp diminution (from northeast to southwest) in shallow seismicity and with the southwest limit of aftershocks (and, presumably, of the rupture zone) of the great 1964 Alaska megathrust earthquake (Fisher and others, 1981).

In view of the many tectonic and geophysical changes across this transverse structural zone, we consider it plausible that a complex stress field associated with its intersection with the Bruin Bay Fault zone facilitates the ascent of rear-arc basaltic magma elsewhere denied access to the upper crust.

\section{Acknowledgments}

The rocks studied were sampled in the course of a regional search for exposed sections that contain ash layers erupted from the Katmai volcanic cluster (Fierstein, 2007), a project supported by the Alaska Volcano Observatory. John Paskievitch arranged essential logistical support. Sam Egli flew us to the outcrops and got us back to King Salmon every time, rain or shine. In King Salmon, the ever-helpful personnel of the U.S. Fish and Wildlife Service provided bunkspace for R\&R. The late Dave Siems performed the XRF analyses, and James Saburomaru helped with the age determinations. Bruce Houghton provided stimulating perspectives and companionship on a trip to Blue Mountain and Ukinrek Maars, and Bill Evans sent us a preprint of his insightful paper on the ongoing gas discharge. We are grateful to Bill Evans, Mike Fisher, and Tina Neal for their helpful reviews of the manuscript. 


\section{References Cited}

Bacon, C.R., and Druitt, T.H., 1988, Compositional evolution of the zoned calcalkaline magma chamber of Mount Mazama, Crater Lake, Oregon: Contributions to Mineralogy and Petrology, v. 98, p. 224-256.

Barnes, I., and McCoy, G.A., 1979, Possible role of mantlederived $\mathrm{CO}_{2}$ in causing two "phreatic" explosions in Alaska: Geology, v. 7, no. 9, p. 434-435.

Calvert, A.T., Moore, R.B., and McGimsey, R.G., 2005, Argon geochronology of late Pleistocene to Holocene Westdahl Volcano, Unimak Island, Alaska, in Haeussler, P.J., and Galloway, J.P., eds., Studies by the U.S. Geological Survey in Alaska, 2004: U.S. Geological Survey Professional Paper 1709-D, http://pubs.usgs.gov/pp/pp1709d/.

Dalrymple, G.B., 1989, The GLM continuous laser system for ${ }^{40} \mathrm{Ar} /{ }^{39} \mathrm{Ar}$ dating; description and performance characteristics, in Shanks, W.C., III, and Criss, R.E., eds., New frontiers in stable isotopic research; laser probes, ion probes, and small-sample analysis: U.S. Geological Survey Bulletin 1890, p. 89-96.

Detterman, R.L., Case, J.E., Miller, J.W., Wilson, F.H., and Yount, M.E., 1996, Stratigraphic framework of the Alaska Peninsula: U.S. Geological Survey Bulletin 1969-A, 74 p.

Detterman, R.L., Case, J.E., Wilson, F.H., and Yount, M.E., 1987a, Geologic map of the Ugashik, Bristol Bay, and western part of Karluk quadrangles, Alaska: U.S. Geological Survey Miscellaneous Investigations Series Map I-1685, scale 1:250,000.

Detterman, R.L., Miller, T.P., Yount, M.E., and Wilson, F.H., 1981, Geologic map of the Chignik and Sutwik Island quadrangles, Alaska: U.S. Geological Survey Miscellaneous Investigations Series Map I-1229, scale 1:250,000.

Detterman, R.L., and Reed, B.L., 1980, Stratigraphy, structure, and economic geology of the Iliamna quadrangle, Alaska: U.S. Geological Survey Bulletin 1368-B, 86 p.

Detterman, R.L., Wilson, F.H., Yount, M.E., and Miller, T.P., 1987b, Quaternary geologic map of the Ugashik, Bristol Bay, and western part of Karluk quadrangles, Alaska: U.S. Geological Survey Miscellaneous Investigations Series Map I-1801, scale 1:250,000.

Evans, W.C., Bergfeld, D., Mc Gimsey, R.G., and Hunt, A.G., 2007, Magmatic gas efflux at the Ukinrek Maars, Alaska, in Bullen, T.D., and Wang, Y., eds., International Symposium on Water-Rock Interaction, 12th, Kunming, P.R.C., 2007, Proceedings: Leiden, A.A. Balkema, v. 1, p. 65-70.

Fierstein, J., 2007, Explosive eruptive record in the Katmai region, Alaska Peninsula; an overview: Bulletin of Volcanology, v. 69, p. 469-509.

Fierstein, J., and Hildreth, W., in press, Kaguyak dome field and its Holocene caldera, Alaska Peninsula: Bulletin of Volcanology.
Fisher, M.A., Bruns, T.R., and von Huene, R., 1981, Transverse tectonic boundaries near Kodiak Island, Alaska: Geological Society of America Bulletin, v. 92, no. 1, p. 10-18.

Fliedner, M.M., and Klemperer, S.L., 2000, Crustal structure transition from oceanic arc to continental arc, eastern Aleutian Islands and Alaska Peninsula: Earth and Planetary Science Letters, v. 179, no. 3-4, p. 567-579.

Hildreth, W., and Fierstein, J., 2000, Katmai volcanic cluster and the great eruption of 1912: Geological Society of America Bulletin, v. 112, no. 10, p. 1594-1620.

Hildreth, W., and Fierstein, J., 2003, Geologic map of the Katmai volcanic cluster, Katmai National Park, Alaska: U.S. Geological Survey Geologic Investigations Series Map I-2778, 43 p., scale 1:63,360.

Hildreth, W., Fierstein, J., Lanphere, M.A., and Siems, D.F., 2002, Mount Griggs; a compositionally distinctive Quaternary stratovolcano behind the main volcanic line in Katmai National Park, in Wilson, F.H., and Galloway, J.P., eds., Studies by the U.S. Geological Survey in Alaska, 2000: U.S. Geological Survey Professional Paper 1662, p. 87-112.

Hildreth, W., Fierstein, J., Siems, D.F., Budahn, J.R., and Ruíz, J., 2004, Rear-arc vs. arc-front volcanoes in the Katmai reach of the Alaska Peninsula; a critical appraisal of acrossarc compositional variation: Contributions to Mineralogy and Petrology, v. 147, no. 3, p. 243-275.

Hildreth, W., Lanphere, M.A., and Fierstein, J., 2003, Geochronology and eruptive history of the Katmai volcanic cluster, Alaska Peninsula: Earth and Planetary Science Letters, v. 214, no. 1-2, p. 93-114.

Irvine, T.N., and Baragar, W.R.A., 1971, A guide to the chemical classification of the common volcanic rocks: Canadian Journal of Earth Sciences, v. 8, no. 5, p. 523-548.

Kienle, J., Kyle, P.R., Self, S., Motyka, R.J., and Lorenz, V., 1980, Ukinrek Maars, Alaska; I, April 1977 eruption sequence, petrology and tectonic setting: Journal of Volcanology and Geothermal Research, v. 7, no. 1-2, p. 11-37.

Kienle, J., Swanson, S.E., and Pulpan, H., 1983, Magmatism and subduction in the eastern Aleutian arc, in Shimozuru, D., and Yokoyama, I., eds., Arc volcanism; physics and tectonics: Tokyo, Terra Scientific, p. 191-224.

Lanphere, M.A., and Dalrymple, G.B., 2000, First-principles calibration of ${ }^{38} \mathrm{Ar}$ tracers; implications for the ages of ${ }^{40} \mathrm{Ar} /{ }^{39} \mathrm{Ar}$ fluence monitors: U.S. Geological Survey Professional Paper 1621, 10 p.

Le Bas, M.J., Le Maitre, R.W., Streckeisen, A., and Zanettin, B., 1986, Chemical classification of volcanic rocks based on the total alkali-silica diagram: Journal of Petrology, v. 27, no. 3, p. 745-750.

Lu, Z., Wicks, C., Jr., Dzurisin, D., Power, J.A., Moran, S.C., and Thatcher, W., 2002, Magmatic inflation at a dormant stratovolcano; 1996-1998 activity at Mount Peulik volcano, Alaska, revealed by satellite radar interferom- 
etry: Journal of Geophysical Research, v. 107, no. B7, doi:10.1029/2001JB000471.

Macdonald, G.A., and Katsura, T., 1964, Chemical composition of Hawaiian lavas: Journal of Petrology, v. 5, no. 1, p. 82-133.

MacNeil, F.S., Wolfe, J.A., Miller, D.J., and Hopkins, D.M., 1961, Correlation of Tertiary formations of Alaska: American Association of Petroleum Geologists Bulletin, v. 45, no. 11, p. 1801-1809.

Miller, T.P., 2004, Geology of the Ugashik-Mount Peulik volcanic center, Alaska: U.S. Geological Survey Open-File Report 2004-1009, 19 p.

Miller, T.P., McGimsey, R.G., Richter, D.H., Riehle, J.R., Nye, C.J., Yount, M.E., and Dumoulin, J.A., 1998, Catalog of the historically active volcanoes of Alaska: U.S. Geological Survey Open-File Report 98-582, 104 p.

Moore, J.C., Diebold, J.B., Fisher, M.A., Sample, J.C., Brocher, T.M., Talwani, M., Ewing, J.I., von Huene, R., Rowe, C., Stone, D., and Sawyer, D.S., 1991, EDGE deep seismic reflection transect of the eastern Aleutian arc-trench layered lower crust reveals underplating and continental growth: Geology, v. 19, no. 5, p. 420-424.

Motyka, R.J., Liss, S.A., Nye, C.J., and Moorman, M.A., 1993, Geothermal resources of the Aleutian Arc, Alaska: Alaska Division of Geological and Geophysical Surveys Professional Report 114, 17 p.

Ort, M.H., Wohletz, K., Hooten, J.A., Neal, C.A., and McConnell, V.S., 2000, The Ukinrek Maars eruption, Alaska, 1977; a natural laboratory for the study of phreatomagmatic processes at maars: Terra Nostra, v. 2000/6, p. 396-400.

Plafker, G., and Berg, H.C., 1994, Overview of the geology and tectonic evolution of Alaska, chap. 33 of Plafker, G., and Berg, H.C., eds., The geology of Alaska, v. G-1 of The geology of North America: Boulder, Colo., Geological Society of America, p. 989-1021.

Plafker, G., Moore, J.C., Winkler, G.R., 1994, Geology of the southern Alaska margin, chap. 12 of Plafker, G., and Berg, H.C., eds., The geology of Alaska, v. G-1 of The Geology of North America: Boulder, Colo., Geological Society of America, p. 389-449.

Reed, B.L., and Lanphere, M.A., 1972, Generalized geologic map of the Alaska-Aleutian Range batholith showing potassium-argon ages of the plutonic rocks: U.S. Geological Survey Miscellaneous Field Studies Map MF-372, scale $1: 1,000,000$.

Reed, B.L., and Lanphere, M.A., 1973, Alaska-Aleutian Range batholith; geochronology, chemistry, and relationship to circum-Pacific plutonism: Geological Society of America Bulletin, v. 84, no. 8, p. 2583-2609.

Riehle, J.R., Detterman, R.L., Yount, M.E., and Miller, J.W., 1993, Geologic map of the Mount Katmai quadrangle and adjacent parts of the Naknek and Afognak quadrangles, Alaska: U.S. Geological Survey Miscellaneous Investiga- tions Series Map I-2204, scale 1:250,000.

Self, S., Kienle, J., and Huot, J.-P., 1980, Ukinrek Maars, Alaska; II, Deposits and formation of the 1977 craters: Journal of Volcanology and Geothermal Research, v. 7, no. 1-2, p. 39-65.

Shackleton, N.J., 1995, New data on the evolution of Pliocene climatic variability, in Vrba, E.S., Denton, G.H., Partridge, T.C., and Burckle, L.H., eds., Paleoclimate and evolution with emphasis on human origins: New Haven, Conn., Yale University Press, p. 242-248.

Siems, D.F., 2000, The determination of 30 elements in geological materials by energy-dispersive X-ray fluorescence spectrometry: U.S. Geological Survey Open-File Report 00-475, 13 p.

Smith, W.R., and Baker, A.A., 1924, The Cold Bay-Chignik district, in Brooks, A.F., and others, Mineral resources of Alaska; report on progress of investigations in 1922: U.S. Geological Survey Bulletin 755, p. 151-222.

Symonds, R.B., Ritchie, B.E., McGimsey, R.G., Ort, M.H., Poreda, R.J., Evans, W.C., and Janik, C.J., 1997, Investigations of gas seeps and springs in the vicinity of Gas Rocks, south shore Becharof Lake, Alaska: U.S. Geological Survey Open-File Report 97-127, 31 p.

Waring, G.A., 1917, Mineral springs of Alaska: U.S. Geological Survey Water-Supply Paper 418, 114 p.

Wilson, F.H., and Shew, N., 1992, Map and tables showing geochronology and whole-rock geochemistry of selected samples, Ugashik and part of Karluk quadrangles, Alaska: U.S. Geological Survey Miscellaneous Field Studies Map MF-1539-E, 34 p., scale 1:250,000.

Wood, C.A., and Kienle, J., eds., 1990, Volcanoes of North America; United States and Canada: Cambridge, U.K., Cambridge University Press, 354 p.

York, D., 1969, Least squares fitting of a straight line with correlated errors: Earth and Planetary Science Letters, v. 5, no. 5, p. 320-324.

\section{Appendix: Geochronologic Methods}

Samples for ${ }^{40} \mathrm{Ar} /{ }^{39} \mathrm{Ar}$ dating were chosen by using three basic criteria: (1) freshness, to minimize contaminant argon; (2) crystallinity, to ensure that samples retained radiogenic Ar since eruption; and (3) coarse groundmass textures, to minimize complications during irradiation. The analyzed samples had no visible alteration minerals, contained $<3$ volume percent glass, and had coarse groundmass textures (groundmass feldspar grain size, $>10 \mu \mathrm{m}$ ). Rocks were crushed in a roller mill, ultrasonicated in deionized water, sized to 250 to $350 \mu \mathrm{m}$ diameter, stripped of phenocrysts magnetically, and handpicked for purity. We analyzed about $150 \mathrm{mg}$ of each sample. 
Separates were wrapped in pure copper foil, encapsulated in quartz tubing along with Taylor Creek sanidine monitor minerals, shielded with a single wrap of 0.58-mm-thick $\mathrm{Cd}$ foil, loaded into an $\mathrm{Al}$ irradiation tube, and irradiated for 2 hours in the central thimble of the TRIGA reactor at the USGS laboratory in Denver, Colo. The base of the irradiation tube was positioned $2 \mathrm{~cm}$ above the reactor centerline, and the tube was rotated continuously during irradiation. Taylor Creek sanidine (TCR-2, 27.87 Ma) is a Menlo Park internal standard calibrated to SB-3 biotite (Lanphere and Dalrymple, 2000).

The USGS Menlo Park ${ }^{40} \mathrm{Ar} /{ }^{39} \mathrm{Ar}$ facility is equipped with both a $\mathrm{CO}_{2}$ laser and a Staudacher-type resistance furnace attached to an all-metal extraction line. An early version of the extraction line and spectrometer was described by Dalrymple (1989), and pertinent modifications are outlined below. Six sanidine fractions from each of four monitor packets were fused with the laser, extracted gas was cleaned with two SAES ST-172 getters, and remaining noble gases were analyzed on a MAP 216 mass spectrometer fitted with a Baur-Signer source and a Johnston MM1 multiplier run at $2.1 \mathrm{kV}$. The $J$ neutron-flux parameter for each sample packet was calculated from a quadratic fit to monitor data from four points along the irradiation tube.

Sample packets were heated stepwise in the resistance furnace for 10 minutes at each listed temperature, controlled to within $\pm 1{ }^{\circ} \mathrm{C}$ with an optical infrared sensor. Extracted gas was cleaned for 15 minutes with the two getters, and the resulting gas was analyzed on the MAP 216 mass spectrometer. Isotopic intensities were regressed back to inlet time. Each mass intensity was corrected for mass-spectrometer baseline, and extraction-line backgrounds were run every three to five heating steps. Hot blanks were run but not corrected from these samples because the blank was small and atmospheric in composition. Mass discrimination was measured by using atmospheric $\mathrm{Ar}$, and ${ }^{40} \mathrm{Ar} /{ }^{36} \mathrm{Ar}$ ranged from 286.63 to 286.75 for these samples. Correction factors for Ar isotopes produced from $\mathrm{K}$ and $\mathrm{Ca}$ during irradiation were determined by using coirradiated synthetic $\mathrm{K}$ glass and $\mathrm{CaF}_{2}$.

Sample ratios and ages were calculated by using custom software. To illustrate our results, we present two types of graphs (fig. 9): (1) age-spectrum diagrams with stacked $\mathrm{K} / \mathrm{Ca}$ and $\mathrm{K} / \mathrm{Cl}$ ratios, and radiogenic-yield plots; and (2) isotope-correlation (isochron) diagrams. The age-spectrum diagrams plot the apparent age and $\pm 1 \sigma$ error of each gas fraction versus the cumulative percentage of ${ }^{39} \mathrm{Ar}$ released. Apparent ages were calculated by assuming that the nonradiogenic Ar released at each heating step has the modern-day atmospheric ${ }^{40} \mathrm{Ar} /{ }^{36} \mathrm{Ar}$ ratio, presently defined as 295.5 but normalized to atmosphere by the mass-discrimination measurement described above. Because the samples are young, we used a standard isochron diagram that plots ${ }^{39} \mathrm{Ar} /{ }^{36} \mathrm{Ar}$ against ${ }^{40} \mathrm{Ar} /{ }^{36} \mathrm{Ar}$; inverse isochron analysis $\left({ }^{39} \mathrm{Ar} /{ }^{40} \mathrm{Ar}\right.$ versus ${ }^{36} \mathrm{Ar} /{ }^{40} \mathrm{Ar}$ ratios) yields indistinguishable results but illustrates them less clearly. The weighted-regression line of York (1969) was fitted to the data, where the $y$-axis intercept corresponds to the isotope ratio of the trapped component and the slope of the line is proportional to age. A mean square of weighted deviates (MSWD) was calculated for the isochron data to estimate goodness of fit, where MSWD>>1 indicates excess dispersion or multiple trapped components and MSWD $<<1$ suggests overestimation of errors. 